\title{
Impacts of drought and temperature stress on coffee physiology and production: a review
}

\author{
Fábio M. DaMatta ${ }^{1 *}$ and José D. Cochicho Ramalho ${ }^{2,3}$
}

\begin{abstract}
${ }^{1}$ Departamento de Biologia Vegetal, Universidade Federal de Viçosa, 36570-000 Viçosa, MG, Brasil. ${ }^{2}$ Centro de Ecofisiologia, Bioquímica e Biotecnologia Vegetal, Instituto de Investigação Científica Tropical, Quinta do Marquês, Av. República, 2784-505 Oeiras, Portugal; ${ }^{3}$ UBIAFCT-UNL, 2829-516 Monte da Caparica, Portugal.*Corresponding author:fdamatta@ufv.br
\end{abstract}

Overall, drought and unfavourable temperatures are the major climatic limitations for coffee production. These limitations are expected to become increasingly important in several coffee growing regions due to the recognized changes in global climate, and also because coffee cultivation has spread towards marginal lands, where water shortage and unfavourable temperatures constitute major constraints to coffee yield. In this review, we examine the impacts of such limitations on the physiology, and consequently on the production of mainly Coffea arabica and C. canephora, which account for about $99 \%$ of the world coffee bean production. The first section deals with climatic factors and the coffee plant's requirements. The importance of controlling oxidative stress for the expression of drought and cold tolerance abilities is emphasized in the second section. In the third section, we examine the impacts of drought on cell-water relations, stomatal behaviour and water use, photosynthesis and crop yield, carbon and nitrogen metabolism, root growth and characteristics, and on drought tolerance. In the fourth section, the impacts of low positive and high temperatures on coffee physiology are discussed; some insights about effects of negative temperatures are also presented. Finally, the last section deals with shading in harsh environments as a mean of buffering climatic fluctuations, as well as of increasing environmental sustainability in coffee exploitation.

Key words: Coffea, chilling, frost, heat, photosynthesis, water deficit, water use, yield.

Impactos da seca e do estresse térmico sobre a fisiologia e a produção do cafeeiro: uma revisão: De modo geral, seca e temperaturas desfavoráveis são as principais limitações climáticas à produção do cafeeiro. A importância de tais limitações deve aumentar, em função das mudanças reconhecidas no clima global e, também, porque a cafeicultura vem sendo expandida para regiões marginais onde secas e temperaturas desfavoráveis se constituem em grandes limitações à produção do café. Nesta revisão, analisam-se os impactos de tais limitações sobre a fisiologia, e por extensão sobre a produção, principalmente de Coffea arabica e C. canephora, que respondem por cerca de $99 \%$ da produção mundial. A primeira seção deste trabalho aborda as exigências climáticas do cafeeiro. Na segunda seção, enfatiza-se a importância do controle do estresse oxidativo para a expressão da capacidade de tolerância à seca e ao frio. Na terceira, examinam-se os impactos da seca sobre as relações hídricas em nível celular, comportamento estomático e uso da água, fotossíntese e produção, metabolismo do carbono e do nitrogênio, características e respostas de crescimento das raízes, além da tolerância à seca. Na quarta seção, discutem-se impactos tanto de baixas temperaturas positivas como de altas temperaturas sobre a fisiologia do cafeeiro; apresentam-se, também, algumas informações sobre efeitos de temperaturas negativas. Finalmente, na última seção, discute-se sobre o sombreamento como um meio de tamponamento das flutuações climáticas e de aumento da sustentabilidade ambiente para a cafeicultura.

Palavras-chave: Calor, Coffea, déficit hídrico, fotossíntese, frio, geada, produção, uso da água.

\footnotetext{
Abbreviations

$A$ - net photosynthetic rate; $A_{\max }$ - photosynthetic capacity, obtained under light and $\mathrm{CO}_{2}$ saturating conditions and optimal temperature; APX - ascorbate peroxidase; chl - chlorophyll; C16:0 - palmitic acid; C16:1t - trans- $\Delta^{3}$-hexadecenoic acid; C18:0 - stearic acid; C18:3 - linolenic acid; $D$ - vapour pressure deficit; DGDG - digalactosyldiacylglycerol; $E$ - transpiration rate; $E T_{0}$ - reference evapotranspiration; $E T_{\mathrm{c}}$ - crop evapotranspiration; FA - fatty acid; $g_{\mathrm{b}}-$ boundary conductance to water vapour; $g_{\mathrm{s}}$ - stomatal conductance to water vapour; $G_{\mathrm{t}}$ - total hydraulic conductance of the soil-leaf pathway; $K_{\mathrm{c}}$ - crop coefficient; LAI - leaf area index; LHC - light-harvesting complexes from photosystems; MGDG - monogalactosyldiacylglycerol; ${ }^{1} \mathrm{O}_{2}-$ singlet oxygen; $\mathrm{O}_{2}{ }^{-{ }^{-}}-$superoxide radical; ${ }^{\circ} \mathrm{OH}$ - hydroxyl radical; PG - phosphatidylglycerol; PS - photosystem; ROS - reactive oxygen species; rubisco - ribulose-1,5-bisphosphate carboxylase/ oxygenase; RuBP - ribulose-1,5-bisphosphate; RWC - relative water content; SOD - superoxide dismutase; $\Delta$ - stable carbon isotope discrimination; $\varepsilon$ - bulk modulus of elasticity; $\Psi_{\mathrm{w}}$ - water potential; $\Omega$ - decoupling factor
} 


\section{INTRODUCTION}

Under field conditions, plant performance in terms of growth, development, biomass accumulation and yield depends on acclimation ability to the environmental changes and stresses, exercising specific tolerance mechanisms that involve a complex network of biochemical and molecular processes (Wang et al., 2003). In fact, abiotic stresses such as extreme temperatures, drought, salinity or chemical toxicity represent serious limitations to agriculture, more than halving average yields for major crop species (Bray et al., 2000).

Among some 90 species of the Coffea genus, C. arabica L. (arabica coffee) and C. canephora Pierre (robusta coffee) economically dominate the world coffee trade, being responsible for about $99 \%$ of world bean production. Presently, arabica coffee accounts for about $62 \%$ of coffee consumed, and robusta coffee for the rest. Compared with arabica, robusta coffee generally appears to be more vigorous, productive and robust, but the quality of the beverage derived from its beans is considerably inferior to that from arabica (Coste, 1992). Robusta is the most widely cultivated variety of $C$. canephora in the world, so that the name of this variety is used to designate the common name of the species. Nevertheless, in Brazil, Kouillou (also known as Conilon) is practically the sole cultivated variety of $C$. canephora. Within C. arabica, Catuaí and Mundo Novo are the most traditional cropped cultivars, but many others are also economically important worldwide.

Among natural commodities, coffee has a monetary value surpassed only by oil. Its international trade generates over US\$ 90,000 million each year and involves about 500 million people in its management, from cultivation to the final product for consumption. Coffee is currently grown in some 80 countries in four continents. Brazil is the world's largest coffee producer, followed alternately by Colombia and Vietnam. Many African countries including Uganda, Burundi, Rwanda and Ethiopia have coffee as their main source of foreign exchange. In addition, the vast majority of coffee plantations worldwide belong to smallholders, which makes the activity highly important in maintaining rural lifestyles, providing better incomes, and wealth distribution.

The coffee crop is confined to the inter-tropical zone, from $20-25^{\circ} \mathrm{N}$ in Hawaii down to $24^{\circ} \mathrm{S}$ in Brazil, mainly due to ecological factors related to temperature and humidity (Smith, 1989). Both low positive and high temperatures can remarkably affect coffee yields, although this is not always easily perceived. Nonetheless, within the referred zone, the strongest climatic limitations of coffee are frost and drought.
Frost easily damages and eventually completely kills the coffee tree, as indeed occurs from time to time either in southern Brazil or, closer to the equator, at altitudes around $2000 \mathrm{~m}$ and above. Drought episodes are much more frequent than frosts, so drought is considered the major environmental stress affecting coffee production in most coffee-growing countries. In some marginal regions with no irrigation, coffee yields may decrease as much as $80 \%$ in very dry years. The international coffee prices are strongly affected by drought and frost events, as was the case in the mid 1990's, when two devastating frosts in the southern growing regions of Brazil caused the price to almost triple.

In the last 15 years, reviews focusing on the physiology of arabica coffee (Rena et al., 1994; Barros et al., 1995, 1999; Carr, 2001; Maestri et al., 2001) and both arabica and robusta coffee (DaMatta and Rena, 2001, 2002a,b; DaMatta, 2004a) have been published. The present review is mainly focused on recent advances concerning drought and temperature stress effects on the physiology of these two species. Unless otherwise indicated, information dealing with robusta coffee concerns the variety Kouillou. Effects of drought on both vegetative and reproductive growth will not be examined here, taking into account that little or nothing had been published on the subject following the above quoted reviews. This review is organized into sections dealing with (i) climatic factors and requirements, (ii) the importance of oxidative stress control to the expression of drought and extreme temperature tolerance, (iii) impact and plant responses to drought and to (iv) extreme temperature stress, and (v) shading in harsh environments.

\section{CLIMATIC FACTORS AND REQUIREMENTS}

Before examining the effects of drought and temperature stress on the physiology of the coffee tree, a brief description of the basic climatic characteristics of the regions where coffee probably evolved is required, in order to ensure a better understanding of the responses of the plant to environmental constraints.

Arabica coffee is native to Ethiopian tropical forests at altitudes of 1600-2800 m. In this region, air temperature shows little seasonal fluctuation, with an annual average of about $20^{\circ} \mathrm{C}$. Rainfall is well distributed, varying from 1600 to more than $2000 \mathrm{~mm}$, with a dry season lasting three to four months coinciding with the coolest period. In this environment, arabica coffee became established as an understorey shrub (Sylvain, 1955). Robusta coffee, in turn, is native to the lowland forests of the Congo River basin, which 
extend up to Lake Victoria in Uganda. The altitude of this region varies from sea level up to $1200 \mathrm{~m}$ in Uganda. This species developed as a midstorey tree in a dense, equatorial rainforest. In that region, the average temperature is between $24-26^{\circ} \mathrm{C}$, without large oscillations, with abundant rainfall superior to $2000 \mathrm{~mm}$ distributed over a 9- to 10-month period, and atmospheric humidity frequently approaching saturation (Coste, 1992).

The optimum mean annual temperature range for arabica coffee is $18-21^{\circ} \mathrm{C}$ (Alègre, 1959). Above $23^{\circ} \mathrm{C}$, development and ripening of fruits are accelerated, often leading to loss of quality (Camargo, 1985). Continuous exposure to temperatures as high as $30^{\circ} \mathrm{C}$ could result in not only depressed growth but also in abnormalities such as yellowing of leaves and growth of tumors at the base of the stem (Franco, 1958). A relatively high temperature during blossoming, especially if associated with a prolonged dry season, may cause abortion of flowers (Camargo, 1985). It should be noted, however, that selected cultivars under intensive management conditions have allowed arabica coffee plantations to be spread to marginal regions with average temperatures as high as $24-25^{\circ} \mathrm{C}$, with satisfactory yields, such as in the northeast of Brazil (DaMatta, 2004a). On the other hand, in regions with a mean annual temperature below $17-18^{\circ} \mathrm{C}$, growth is largely depressed. Occurrence of frosts, even if sporadic, may strongly limit the economic success of the crop (Camargo, 1985). For robusta coffee, the optimum annual mean temperature ranges from 22 to $26^{\circ} \mathrm{C}$ (Matiello, 1998), or, according to Willson (1999), from 24 to $30^{\circ} \mathrm{C}$. High temperatures can be harmful, especially if the air is dry (Coste, 1992). Robusta is much less adaptable to lower temperatures than arabica coffee. Both leaves and fruits do not withstand temperatures below $5-6^{\circ} \mathrm{C}$ or long periods at $15^{\circ} \mathrm{C}$ (Willson, 1999). As altitude relates to temperature, robusta coffee can be grown between sea level and $800 \mathrm{~m}$, whereas arabica coffee grows best at higher altitudes and is often grown in hilly areas, as in Colombia and Central America. Coffee can also be grown at lower altitudes further from the equator, unless limited by frost, as is the case of arabica coffee in Brazil.

It should be noted that the adequate temperature value changes with the phenological stage of coffee. The optimum temperature for germination of arabica coffee is around 30$32^{\circ} \mathrm{C}$, when it takes about 3 weeks to accomplish the process, while at $17^{\circ} \mathrm{C}$ it requires 3 months (Moraes, 1963; IBC, 1985), whereas above $35^{\circ} \mathrm{C}$ germination is inhibited (Barros et al., 1999). During the first weeks of plant development the optimum temperature is about $30 / 23^{\circ} \mathrm{C}$ (day/night), but with the production of the first branches the values decrease to $26 /$ $20^{\circ} \mathrm{C}$ and approximately after one year they are close to those indicated for mature plants (Moraes, 1963; IARC, 1991; Coste, 1992; Barros et al., 1999). Temperatures up to $30^{\circ} \mathrm{C}$ are also needed for floral bud initiation, but their development, as well as growth of the fruit should occur at values around 23/ 17 C (Carvajal, 1984; Camargo, 1985; Barros et al., 1999). Moreover, for adequate root development, $24-27^{\circ} \mathrm{C}$ seems to be the best range of soil temperature (IBC, 1985).

Rainfall requirements depend on the retention properties of the soil, atmospheric humidity and cloud cover, as well as cultivation practices. The optimum annual rainfall range is 1200-1800 mm for arabica coffee (Alègre, 1959). A similar range seems to be required for robusta, although it adapts better than arabica to intensive rainfall exceeding $2000 \mathrm{~mm}$ (Coste, 1992). For both species, a short dry spell, lasting 24 months, corresponding to the quiescent growth phase, is important to stimulate flowering (Haarer, 1958). Abundant rainfall throughout the year is often responsible for scattered harvest and low yields. Lack of a dry period can also limit coffee cultivation in lowland tropical regions (Maestri and Barros, 1977).

Air humidity has a significant impact on the vegetative growth of the coffee tree. Robusta successfully grows under high air humidity approaching saturation, or in less humid sites, provided that the dry season is short. However, Kouillou acclimates much better to drier environments than the variety Robusta. In contrast, arabica coffee requires a less humid atmosphere, comparable to that of the Ethiopian highlands (Haarer, 1958; Coste, 1992).

In coffee plantations subjected to large wind shears and advection, crop yield is usually depressed. Wind stress may lead to a reduction of leaf area and internode length of the orthotropic and plagiotropic branches (Caramori et al., 1986), in addition to severely damaging leaves and buds and exacerbating shedding of developing flowers and fruits (Camargo, 1985; Matiello et al., 2002). Hot winds increase crop evapotranspiration $\left(E T_{\mathrm{c}}\right)$ and therefore rainfall (or irrigation) requirements of the trees increase. Where strong wind is frequent, windbreaks or tree shelter is recommended as both may improve crop performance.

\section{CONTROL OF OXIDATIVE STRESS AS A DECISIVE COMPONENT OF DROUGHT AND EXTREME TEMPERATURE TOLERANCE ABILITY}

Primary effects of stresses, such as cold and drought, are often related, causing cellular damage and secondary stresses, 
e.g., osmotic and oxidative stress, resulting in disruption of osmotic and ionic homeostasis and damage to proteins and membranes. These imbalances will trigger downstream signalling and transcription control, which activate mechanisms, such as antifreezing and chaperone functions (e.g., chitinases, glucanases, thaumatin-like proteins, heatshock proteins, late embriogenesis abundant proteins, coldrelated genes), detoxification [e.g., superoxide dismutase (SOD), ascorbate peroxidase (APX)], osmoprotection (e.g., proline, glycine betaine, sugar polyols), etc., that re-establish cellular homeostasis (Wang et al., 2003).

In cellular metabolism, one unavoidable consequence of chloroplast and mitochondrial electron transport is the leakage of electrons to molecular oxygen. In photosynthetic structures this leads to oxidative stress, a common occurrence promoted by several types of environmental limitations (e.g., drought, salinity, cold, heat, etc.) that cause a decrease in energy consumption without a significant reduction in energy capture. This could be explained by (i) a decrease in stomatal conductance $\left(g_{s}\right)$, which limits the access of $\mathrm{CO}_{2}$ to the carboxylation sites, (ii) an overall decrease in the rate of chemical and enzyme reactions (e.g., due to cold), and (iii) specific impairments of the electron transport chain and key metabolic enzymes (such as ribulose-1,5-bisphosphate carboxylase/oxygenase - rubisco). Such impacts do decrease the use of energy and reducing power (causing an increase in the intrathylakoidal $\Delta \mathrm{pH}$ and an over-reduction of the thylakoid electron transport chain) and produce an imbalance between the absorbed energy at the level of light-harvesting complexes (LHC) and its use through photochemistry. Those conditions will increase the probability of the transfer of excitation energy from chlorophyll (chl) to $\mathrm{O}_{2}$, producing ${ }^{1} \mathrm{O}_{2}$, and the addition of electrons at photosystem (PS) I and PSII level, producing $\mathrm{O}_{2}{ }^{-}$that in turn can originate $\mathrm{H}_{2} \mathrm{O}_{2}$ and ${ }^{\circ} \mathrm{OH}$. These highly reactive forms are called reactive oxygen species (ROS) and are responsible for cellular oxidative stress conditions, provoking extensive damage in cell machinery, namely in the illuminated chloroplast that is the major cellular ROS producer and also its primary target (Asada e Takahashi, 1987; Asada, 1994; Alscher et al., 1997; Mano, 2002; Perl-Treves and Perl, 2002). Extensive ROSinduced damage occurs through lipid peroxidation, bleaching of pigments (e.g., in $P_{680}$ ), protein (e.g., D1 protein) and DNA degradation, as well as through enzyme inactivation (Foyer et al., 1994; Niyogi, 1999). This lowers even further the utilization of photons, thereby enhancing the generation of such molecules. In this way, ROS production and content should be kept under strict control and an increased expression of antioxidative scavengers is therefore of paramount importance (Hällgreen and Öquist, 1990; Foyer et al., 1994; Krause, 1994; Adams and Demmig-Adams, 1995; Adams and Barker, 1998).

In order to deal with oxidative stress, plants developed a complex and integrated network of protection mechanisms that avoid the production and/or control the action of the produced ROS. According to its action, these mechanisms may be divided into those that:

1) Promote the reduction of energy capture - a highly efficient way of avoiding a chloroplast energy overcharge is reducing energy absorption by leaves. This may be achieved through leaf movements and rolling, production of reflecting surfaces, movement of chloroplasts to the opposite side of the cell to light incidence, decreases in chl content, etc. Such mechanisms may decrease the absorption of incident radiation by up to $40 \%$ (Larcher, 1995; Lawlor, 2001; Karpinski et al., 2002).

2) Increase the photochemical use or the nonphotochemical dissipation ability of excess energy - improved photochemical use of energy can be achieved through the reinforcement of thylakoid electron transport components, rubisco, etc., allowing the maintenance of thylakoid reduction state (Xu et al., 1999; Kornyeyev et al., 2001). This includes the state-transition mechanism, understood as the migration of LHCs between PSII and PSI that allows a better redistribution of excitation energy. If the LHCs just disconnect from PSII, dissipating the absorbed energy, this will configure a dissipation mechanism that protects $P_{680}$ (Adams and Demmig-Adams, 1995; Horton et al., 1996; Kornyeyev et al., 2001; Karpinski et al., 2002). Other dissipation mechanisms include the photorespiration pathway and the pseudocyclic electron transport process (Mehler Reaction), both of which require complementary mechanisms for $\mathrm{O}_{2}{ }^{--}$removal, as well as increases in both non-photochemical quenching and contents of photoprotective pigments ( $\beta$-carotene, lutein and zeaxanthin), which act through thermal dissipation (Siefermann-Harms, 1988; Young, 1991; De Las Rivas et al., 1993; Krause, 1994; Krivosheeva et al. 1996; Niyogi et al., 1997; Xu et al., 1999; Havaux and Kloppstech 2001; Adams et al., 2002; Foyer, 2002; Karpinski et al., 2002). These processes decrease the production of highly reactive compounds and prevent the over-reduction of the electron transport chain and the overacidification of the thylakoid lumen, which sensitize PSII to photodamage (Müller et al., 2001; Mano, 2002). 
3) Control the production and the level of highly reactive compounds, through the Haliwell-Asada pathway - despite the above cited mechanisms, an over-production of ROS could occur under environmental stress conditions, requiring a complementary line of defence to efficiently remove them. That is the function of the Haliwell-Asada pathway (also known as the ascorbate/glutathione cycle), which involves the action of several scavengers, including enzymes (APX, monodehydroascorbate reductase, dehydroascorbate reductase, glutathione reductase), hydrophilic (ascorbate and reduced glutathione) and lipophilic (zeaxanthin and $\alpha$ tocopherol) molecules (Hällgreen and Öquist, 1990; Foyer et al., 1994; Krause, 1994; Adams and Demmig-Adams, 1995; Alscher et al., 1997; Adams and Barker, 1998; Munné-Bosch and Alegre, 2002; Perl-Treves and Perl, 2002).

4) Promote long-term structural changes - a consolidated acclimation should also involve long-term structural changes at the membrane level, namely quantitative and qualitative changes in lipids and protein components. The ability to maintain de novo synthesis, to repair and replace affected cellular components, is of utmost importance. Also, the maintenance of fluidity of membranes (thus, functionality) is essential for drought and cold tolerance and can be achieved through changes in the balance of lipid classes and fatty acid (FA) saturation (Nishida and Murata, 1996; Routaboul et al., 2000; Xin and Browse, 2000; Iba, 2002). For instance, the increase in the unsaturation level of FA results in a lower transition temperature between the crystal (functional) and gel (non-functional), a quite important feature, as inferred from the fact that most subtropical fruit trees have a transition temperature between 10 and $15^{\circ} \mathrm{C}$, while those from temperate climate have values between 3 and $5^{\circ} \mathrm{C}$ (Harwood, 1997). Opposite changes occur under high temperatures in order to control an over-fluidity promoted by heat. These changes in FA unsaturation levels could be achieved by preferential synthesis of palmitic acid (C16:0) and a decrease in linolenic acid (C18:3).

With regard to arabica coffee plants, peroxidation of membrane lipids plays a decisive role in the high cold sensitivity of roots, probably linked to a limitation in the functioning of antioxidative systems provoked by a decreased respiratory activity. The latter brings about a low availability of reducing power that in turn leads to the failure of antioxidative enzymes to protect lipid membranes, causing a higher root tissue damage and membrane rigidity (Alonso et al., 1997; Queiroz et al., 1998).
A recent set of studies with potted plants of several coffee genotypes, which were submitted to low positive temperatures (Quartin et al., 2000; Campos et al., 2003; Ramalho et al., 2003; Ramalho et al., unpublished results) showed that Icatu (a hybrid of C. arabica x C. canephora, but backcrossed so many times with $C$. arabica that some researchers consider it as an arabica cultivar) exhibited better cold acclimation ability than the other genotypes studied (see also "Low positive temperature stress" section), namely due to the small membrane selectivity loss and peroxidative degradation. This would be related to the maintenance (or increase) in the FA saturation of membrane lipids and the reinforcement of the antioxidative system (observed also in cv. Catuaí). In fact, a higher FA saturation level turns the membranes more resistant to peroxidation, since the double bonds from polyunsaturated FA are the preferential substrate for peroxidative enzymes and ROS attack. Such changes allow the coffee plants to maintain higher photosynthetic activity due to an organized and functional membrane structure (still, more rigid) less sensitive to ROS. Such qualitative changes in membrane lipids seem also to play an important role in acclimation of the coffee tree to other conditions that promote oxidative stress, such as high-irradiance exposure (Ramalho et al., 1998), becoming important in a quite short (8 h) time (Gascó et al., 2004).

Changes in the lipid classes concerning cold tolerance are also important, namely those in the galactolipids mono galactosyldiacylglycerol (MGDG) and digalactosyldiacylg lycerol (DGDG), which are the main lipid components of thylakoids, representing up to about $60 \%$ (Harwood, 1988; 1997; Xin and Browse, 2000). Decreases in the MGDG/ DGDG ratio due to a preferential DGDG synthesis have been related to higher tolerance to cold (Hurry et al., 1998; Iba, 2002; Karpinski et al., 2002) and drought (Gigon et al., 2004). However, such changes were insufficient to increase cold tolerance, as found in $C$. dewevrei, C. canephora cv. Apoatã and in the hybrid Piatã (C. arabica x C. dewevrei) which showed decreases of about $14 \%, 27 \%$ and $41 \%$, respectively in the MGDG/DGDG ratio, but proved to be cold sensitive. Instead, Icatu (and partially C. arabica cv. Catuaí), that was more cold tolerant, displayed small changes in these lipid characteristics, suggesting that the MGDG/DGDG ratio changes are not decisive for low temperature acclimation in coffee (Campos et al., 2003). On the other hand, Icatu showed the lower content ( $c a .20 \%$ ) of saturated FA (mainly C16:0 and stearic acid - C18:0) of phosphatidylglycerol (PG) under cold conditions, in contrast to the almost $40 \%$ 
observed in $C$. dewevrei, with Catuaí having an intermediate value, slightly below $30 \%$. Icatu (and Catuaí) also displayed the highest content of trans- $\Delta^{3}$-hexadecenoic acid (C16:1t), the major FA of PG that is characteristic of chloroplasts (Campos et al., 2003). Altogether, such changes would largely explain the better cold tolerance of Icatu since such tolerance has been related to a much lower FA saturation level in PG than in cold-sensitive cultivars. Moreover, trans- $\Delta^{3}$-hexadecenoic acid has been implicated in the stabilization/association of LHC with the reaction centres, as well as in the process of replacement of damaged D1 protein (Horváth et al., 1987; Huner et al., 1989; Moon et al., 1995; Harwood, 1997; Iba, 2002). On this evidence, we suggest that the FA constitution and the degree of saturation of PG in chloroplast membranes play an important role in cold tolerance in coffee. Nevertheless, it should be kept in mind that an equilibrium should be reached between changes that allow a higher membrane tolerance to peroxidation but will turn the membrane more rigid at low temperatures (higher FA saturation level) and those that promote membrane fluidity but allow ROS attack (lower FA saturation level).

The role of oxidative stress control for the expression of cold acclimation ability could be inferred from the comparison between several coffee genotypes with different cold tolerance, being cv. Apoatã and $C$. dewevrei more sensitive and Icatu more tolerant, as already mentioned. Icatu showed a lower increase in membrane selectivity loss and in peroxidative degradation, that could be related to the maintenance of (or increase in) the global FA saturation level of membrane lipids and the reinforcement of the antioxidative system (observed also in Catuaí), responsible for maintaining an organized and functional membrane structure less sensitive to ROS attack on the double bonds of unsaturated FA (Quartin et al., 2000; Campos et al., 2003; Ramalho et al., 2003; Ramalho et al., unpublished results). In contrast, Apoatã and Piatã submitted to chilling showed a strong increase (31\% and $21 \%$, respectively) in FA unsaturation, which could help to maintain membrane fluidity, but turn it more sensitive to ROS, resulting in higher membrane leakage (Campos et al., 2003). In Icatu, oxidative stress was in fact much more controlled, as inferred from (i) the maintenance $\left({ }^{\circ} \mathrm{OH}\right)$ or decrease $\left(\mathrm{H}_{2} \mathrm{O}_{2}\right)$ of ROS levels, (ii) the strong increase of some photoprotective pigments (e.g., zeaxanthin and lutein) and (iii) the maintenance of high activities of antioxidant enzymes (chloroplast $\mathrm{Cu}, \mathrm{Zn}-\mathrm{SOD}$ and APX), especially during the cold exposure period (Lidon et al., 2004; Ramalho et al., unpublished data). On the other hand, it is reasonable to admit that with temperatures close to $0^{\circ} \mathrm{C}$ the antioxidative mechanisms based on enzymes will be severely suppressed in vivo (Geiger et al., 1992; Adams and Demmig-Adams, 1995), turning even more important the reinforcement of the xanthophylls (zeaxanthin and lutein) and $\beta$-carotene contents in the LHC (Pogson et al., 1998; Havaux and Niyogi, 1999; Karpinski et al., 2002). This justifies the strong increases (and the highest absolute contents) in those pigments in Icatu (and partially in Catuaí) and helps to explain its relatively high-cold tolerance (Ramalho et al., 2003; Ramalho et al., unpublished results).

The above results reinforce, in our opinion, that the acquirement of cold tolerance of the coffee photosynthetic apparatus (and thus, of the cell) is mostly related to the control of oxidative stress, achieved through the presence and/or reinforcement of antioxidative mechanisms, as previously reported under photoinhibitory conditions induced by high irradiance (Ramalho et al., 1998, 2000). It is recognized that under cold the photochemical use of energy absorbed by chl is greatly diminished, leading to an accumulation of excited state molecules (e.g., $\left.{ }^{3} \mathrm{chl} *,{ }^{1} \mathrm{chl},{ }^{1} \mathrm{O}_{2}\right)$ in the pigment bed and to the over-production of ROS. Furthermore, changes in the redox potential are implicated in the induction of gene expression of ROS scavenging enzymes, which agrees with the decisive role of those enzymes in the acclimation to cold (Karpinski et al., 2002; Mano, 2002; Perl-Treves and Perl, 2002). That also underlines the reason for the similarity of the defence mechanisms induced by cold and other environmental stresses (particularly by drought) that limit the photosynthetic metabolism.

It should be remembered that in tropical areas both low and high temperatures and water deficit may occur concomitantly in field conditions. As such, it is not unusual that oxidative stress control is of common importance for both of these environmental limitations. Few studies have been undertaken in order to associate oxidative stress and drought (see definition below) tolerance in coffee. Lima et al. (2002), from a study of two clones of robusta coffee rapidly drought stressed, observed remarkably larger increases in the activity of the antioxidant system in the drought-tolerant clone 120 than in the drought-sensitive clone 109A, when the net photosynthetic rate $(A)$ in both was suppressed upon discontinuing irrigation. They also showed that the extent of cellular damage, evaluated via lipid peroxidation and electrolyte leakage, was substantially lower in the clone 120 than in the clone 109A. Therefore, Lima and co-workers proposed that drought tolerance in robusta coffee might be at 
least partially associated with increased activity of antioxidant enzymes (e.g., SOD, APX, catalase), as has been noted in different drought-tolerant species and genotypes (Smirnoff, 1995). In another study, Pinheiro et al. (2004) subjected four clones of robusta (14 and 120, drought-tolerant; 46 and 109A, drought-sensitive) to long-term drought until water potential $\left(\Psi_{\mathrm{w}}\right)$ before dawn reached -3.0 MPa. They found that induction of defence mechanisms against oxidative stress triggered by drought was greater in drought-sensitive than in drought-tolerant clones. Since the extent of cellular damage was comparatively similar or smaller in the latter, an increased oxidative process suffered by the sensitive clones should have occurred. However, Pinheiro et al. (2004) were unable to distinguish the drought-tolerant clone 14 from the drought-sensitive clones 46 and 109A in terms of defence mechanisms to cope with paraquat-induced oxidative stress, and they then proposed that there would be no overall link between oxidative stress and drought tolerance. Nonetheless, revisiting the results of Pinheiro et al. (2004) allow us to infer that the drought-tolerant clone 120 , which is able to endure long drought spells with acceptable yields under this condition (but not the tolerant clone 14), showed an enhanced ability to cope with paraquat-induced oxidative stress compared to the other clones evaluated. This was further reinforced by results of Menezes (2005), who observed that SOD activity in clone 120 was maximum at paraquat concentrations as high as $20 \mu \mathrm{M}$, whereas in the clone 109A such an activity was completely abolished. Therefore, we propose that a more efficient antioxidant system might play a decisive role in drought tolerance in coffee, particularly in genotypes that favour production over survival in dry environments. A comparison of the results of Lima et al. (2002) and Pinheiro et al. (2004) also indicated that, if water deficit proceeds slowly, the coffee plants can acclimate to drought and, as a consequence, they could largely avoid oxidative stress.

\section{IMPACT AND RESPONSES TO DROUGHT STRESS}

From a meteorological point of view, drought refers only to a period in which rainfall fails to keep up with potential evapotranspiration. However, particularly in the tropics, drought episodes are remarkably aggravated by both high solar radiation and high temperature, so drought should be considered as a multidimensional stress (DaMatta, 2003). Here, we will consider drought as an environmental factor that produces water deficit in plants, which is initiated when low $\Psi_{\mathrm{w}}$ develops and cell turgor begins to fall below its maximum value. In contrast to many other stressful events (e.g., frosts), stress caused by drought usually does not occur suddenly, but develops slowly and increases in intensity the longer it lasts. Therefore, the time factor plays a crucial role in survival and/or maintenance of productivity under drought conditions.

As for other stresses, the slow imposition of drought allows the development of a range of time-dependent morphological and physiological acclimation responses. Despite this, many studies concerning drought effects on coffee physiology have been carried out on plants grown in small containers under greenhouse conditions. This has been done in order to rapidly understand the plant's behaviour without the complicating effects of environmental variability. However, such an approach provides only a limited model of natural conditions since (i) growth, particularly of roots, is restricted in potted trees, with observations largely dependent on the rate of stress progression; (ii) soil substrates in pot experiments usually have lower unsaturated hydraulic conductivity than natural soils, thus enhancing the probability of short and local water deficit in the roots; (iii) the air surrounding the plant within a greenhouse is usually isolated from the external atmosphere, thus fully decoupling transpiration; and (iv) if humidity and temperature control within a greenhouse is lacking, evaporative demand may strongly rise due mainly to increased temperature which can reach values as high as $45^{\circ} \mathrm{C}$ or more in the afternoon on sunny summer days (DaMatta, 2003, and references therein).

\section{Water relations}

Comparative analyses of variables of tissue water relations based on pressure-volume curves (Table 1) suggest that irrespective of water supply coffee leaves show a high relative water content (RWC) at the turgor loss point, usually close to $90 \%$, a phenomenon largely associated with low cell-wall elasticity (see below) (DaMatta et al., 1993; Pinheiro et al., 2005). This corresponds to $\Psi_{\mathrm{w}}$ values ranging from -1.5 to $-2.2 \mathrm{MPa}$ for irrigated plants, with lower values for nonirrigated genotypes exhibiting some osmotic adjustment (Table 1), herein defined as a net increased solute concentration. Table 1 indicates that osmotic adjustment is not a general trait observed in coffee under drought conditions, as noted previously (Golberg et al., 1984; DaMatta 2004b). Thus, this mechanism, although it has been generally associated with maintenance of gas exchange in many plant species under drought conditions (Turner, 1997), could hardly explain the stomatal sensitivity of coffee to 
Table 1. Osmotic potential at the turgor loss point $\left(\Psi_{\pi(0)}, \mathrm{MPa}\right)$, bulk modulus of elasticity $(\varepsilon, \mathrm{MPa})$, and relative water content at the turgor loss point $\left(\mathrm{RWC}_{(0)}, \%\right)$ of coffee plants. The first five genotypes belong to the arabica group, Siriema is a hybrid between $C$. arabica and C. racemosa, and the other genotypes belong to the robusta group. Plants were grown under pot (P) or field (F) conditions. When underlined, means for drought-stressed plants differ from those for control plants $(P \leq 0 \cdot 05)$. $n a=$ not available.

\begin{tabular}{|c|c|c|c|c|c|c|c|}
\hline \multirow{2}{*}{ Genotypes } & \multicolumn{3}{|c|}{ Control } & \multicolumn{3}{|c|}{ Drought } & \multirow[t]{2}{*}{ Source } \\
\hline & $\Psi_{\pi(0)}$ & $\varepsilon$ & $\mathrm{RWC}_{(0)}$ & $\Psi_{\pi(0)}$ & $\varepsilon$ & $\mathrm{RWC}_{(0)}$ & \\
\hline Catuaí (P) & -1.48 & 23 & 93.6 & $\underline{-1.81}$ & 24 & 93.6 & DaMatta et al. (1993) \\
\hline Catuaí (F) & -1.59 & 20 & 91.0 & $\underline{-1.84}$ & $\underline{23}$ & $\underline{92.6}$ & DaMatta (unpublished) \\
\hline Catimor (P) & -1.77 & 25 & 93.1 & $\underline{-2.08}$ & 27 & 92.9 & DaMatta et al. (1993) \\
\hline Mundo Novo (P) & -1.57 & 25 & 93.4 & $\underline{-1.91}$ & 25 & 93.2 & DaMatta et al. (1993) \\
\hline Catucaí (P) & -1.71 & 22 & 92.8 & $\underline{-2.14}$ & $\underline{20}$ & $\underline{90.2}$ & Dias and DaMatta (unpublished) \\
\hline Siriema $(\mathrm{P})$ & -1.78 & 21 & 91.4 & $\underline{-2.12}$ & $\underline{18}$ & $\underline{89.9}$ & Dias and DaMatta (unpublished) \\
\hline Conilon (P) & -1.68 & 24 & 91.8 & $\underline{-2.16}$ & $\underline{31}$ & $\underline{93.7}$ & DaMatta et al. (1993) \\
\hline Clone 46 (P) & -2.22 & 19 & 90.1 & -2.31 & 19 & 90.8 & Pinheiro (2004) \\
\hline Clone $46(\mathrm{~F})$ & -1.75 & 8 & $n a$ & $\underline{-2.45}$ & $\underline{25}$ & na & DaMatta et al. (2003) \\
\hline Clone 99 (P) & -2.04 & 13 & $n a$ & $\underline{-2.42}$ & $\underline{22}$ & $n a$ & DaMatta et al. (2002a) \\
\hline Clone $120(\mathrm{P})$ & -2.23 & 18 & 89.6 & -2.37 & 19 & 89.7 & Pinheiro (2004) \\
\hline Clone $120(\mathrm{~F})$ & -2.07 & 16 & $n a$ & -1.88 & $\underline{12}$ & $n a$ & DaMatta et al. (2003) \\
\hline
\end{tabular}

drought. Furthermore, leaf water deficits may develop faster upon discontinuing irrigation in coffee genotypes having greater amplitude of osmotic adjustment (DaMatta, 2004b).

Most work shows a high bulk volumetric modulus of elasticity $(\varepsilon)$ in both arabica and robusta coffee (Table 1; see also Meinzer et al., 1990b), which is associated with low cell-wall elasticity and an efficient stomatal control of transpiration rate $(E)$ (DaMatta, 2004b). Under drought conditions, little difference in $\varepsilon$ has been reported for arabica (18 to $27 \mathrm{MPa}$ ), but such differences appear to be larger (8 to $31 \mathrm{MPa}$ ) within robusta coffee genotypes. In both species, $\varepsilon$ may increase, decrease or remain unresponsive to drought, depending on both genotype and growth conditions (table 1). As discussed by DaMatta et al. (2003), a smaller $\varepsilon$ or a decrease in $\varepsilon$ would allow turgor to decline more slowly as dehydration progresses. This would reduce the fluctuation of both cell turgor and $\Psi_{\mathrm{w}}$, and may have ecological significance by buffering plants against short-term changes in water content. In contrast, for plants with a higher $\varepsilon, \Psi_{\mathrm{w}}$ drops faster during dehydration, thus increasing the soil-plant gradient of $\Psi_{\mathrm{w}}$ and enhancing water uptake. However, if this were true during the morning, an opposite trend would occur in the late afternoon/night, when $\Psi_{\mathrm{w}}$ rises faster due to higher $\varepsilon$, thus ultimately reducing water absorption. Therefore, total water uptake integrated over a $24 \mathrm{~h}$ period would not be as large as often believed in plants with higher $\varepsilon$.
The absence of a defined pattern in osmotic or elastic adjustment in coffee suggests that the preservation of gas exchange and elongation growth should not be closely associated with turgor maintenance, and is consistent with reports in which the adaptive role of such adjustments is questioned (Munns, 1988; Blake and Tschaplinski, 1992; White et al., 1996). In fact, the high RWC maintained by coffee leaves under dehydrating conditions (Nunes, 1976; Josis et al., 1983; DaMatta et al., 1993, 2002a) appears to be a means of avoiding, rather than tolerating, desiccation (DaMatta et al., 1993). Such a high RWC has been associated with conservation of a high symplast volume, which appears to be more directly related to maintenance of gas exchange than turgor per se, as shown by Meinzer et al. (1990b) working with five arabica coffee cultivars subjected to drought. They found that drought-stressed plants were often functioning and showing considerable leaf gas exchange at low or zero turgor. Similar responses appear to occur with field-grown trees of robusta coffee under rain-fed conditions (DaMatta et al., 2003).

It is generally accepted that the increase in cellular osmolarity, which results from the accumulation of non-toxic (thus compatible) osmotically active solutes, is associated with turgor maintenance and osmotic equilibrium without disturbing macromolecular-solvent interactions (Hare et al., 1998). In some species, accumulation of compatible solutes, such as proline and quaternary ammonium compounds, has 
been considered as an adaptation to water shortage that could be used as an index for ranking genotypes with superior performance under drought conditions. In coffee, however, such accumulation does not satisfactorily correlate with drought tolerance in various cultivars of arabica and robusta (Vasudeva et al., 1981; Maestri et al., 1995). In any case, a build-up of such compounds under water-deficit conditions appears to be a sensitive indicator of leaf water status (Maestri et al., 1995). Furthermore, proline accumulation in arabica plants might be related to the injury caused by drought (Mazzafera and Teixeira, 1989).

The physiological mechanisms underlying coffee tolerance to drought appear to be largely related to the strong sensitivity of coffee stomata to both soil (Wormer, 1965; Tesha and Kumar, 1978; Carr, 2001; Pinheiro et al., 2005) and atmospheric (Nunes, 1988; Gutiérrez et al., 1994; Kanechi et al., 1995; Barros et al., 1997; Tausend et al., 2000a, Pinheiro et al., 2005) water deficits. In arabica coffee, $g_{\mathrm{s}}$ appears to be an early indicator of soil drying, showing decreases as soon as one-third of the available soil water has been depleted (Nunes, 1976), although this is not effectively accompanied by proportional reductions in $E$ (Bierhuizen et al., 1969). For both arabica and robusta coffee, $g_{\mathrm{s}}$ has been shown to decrease curvilinearly with decreasing leaf $\Psi_{\mathrm{w}}$, with no apparent threshold value of $\Psi_{\mathrm{w}}$ at which stomatal closure is observed (Nunes and Correia, 1983; Kanechi et al., 1995b; Pinheiro et al., 2005). This suggests a strong sensitivity of coffee stomata to rising internal water deficit. The positive relation between $g_{\mathrm{s}}$ and $\Psi_{\mathrm{w}}$ is expected when soil moisture changes and indirectly affects stomata through a hydraulic feedback (Jones, 1998). Pinheiro et al. (2005) found a rapid recovery of $\Psi_{\mathrm{w}}$ that was accompanied by increased $g_{\mathrm{s}}$ after re-watering drought-stressed (predawn $\Psi_{\mathrm{w}}=-3.0 \mathrm{MPa}$ ) clones of robusta coffee, emphasizing the role of leaf water status on stomatal control. In contrast, Wormer (1965) noted that the degree of stomatal opening in nonirrigated arabica trees did not return to control (irrigated) levels for several months after the rains began, whereas Browning and Fisher (1975) reported that for up to 4 weeks after the relief of stress the degree of stomatal opening was 40-60\% larger than that recorded in continuously irrigated arabica coffee trees. In any case, insufficient information was presented in the last two studies to assess the role of soil water availability on stomatal behaviour.

In field-grown coffee trees, $g_{\text {s }}$ typically is high during early morning and decreases throughout the day as irradiance and vapour pressure deficit $(D)$ between the leaf and air rise
(Gutiérrez et al., 1994; Barros et al., 1997). During the warmer periods of the day, artificial elevation of relative humidity seems to stimulate the coffee stomata to open, especially when soil moisture is not limiting (Tesha and Kumar, 1978). Also, several studies have indicated that $g_{\mathrm{s}}$ is greater in the shade than in sunlit coffee leaves (e.g., Kumar and Tieszen, 1980a; Fanjul et al., 1985; Gutiérrez et al., 1994), particularly throughout the morning. However, this behaviour has been attributed to the sensitivity of the stomata to leaf-to-air $D$ rather than to solar radiation (Nunes, 1988; Gutiérrez et al., 1994; Carr, 2001; DaMatta, 2004a). The remarkable decrease in $g_{\mathrm{s}}$ with rising leaf-to-air $D$ may even occur irrespective of changes in $\Psi_{\mathrm{w}}$ (Gutiérrez et al., 1994; Kanechi et al., 1995a; Barros et al., 1997; Tausend et al., 2000a; Pinheiro et al., 2005), a feed-forward means of stomatal regulation of leaf water status. The relationship between $g_{\mathrm{s}}$ and leaf-to-air $D$ has been described either by a curvilinear (arabica coffee; Fanjul et al., 1985; Hernández et al., 1989; Gutiérrez et al., 1994; Kanechi et al., 1995) or a simple linear (robusta coffee; Pinheiro et al., 2005) decay function. It should be emphasized, however, that in some progenies of robusta coffee $g_{\mathrm{s}}$ does not apparently respond, or does so poorly, to changes in evaporative demand (DaMatta et al., 1997a; Pinheiro et al., 2005). There is also circumstantial evidence that stomatal aperture in C. canephora cv. Apoatã, presumably promoted by chemical signals from roots, is less responsive to decreasing soil water availability than in arabica (Fahl et al., 2001). Because robusta coffee evolved in a wetter region than arabica, the requirement for efficient stomatal control of $E$ would thus be less important for robusta than for arabica coffee (DaMatta, 2003). Considered together, these responses suggest that robusta has a lower stomatal sensitivity to evaporative demand, which leads to a less efficient control of $E$. This might explain, at least partially, why robusta is more responsive to irrigation than arabica coffee (DaMatta, 2004a,b).

In field-grown arabica coffee, Wormer (1965) demonstrated that applications of $\mathrm{N}$ fertilizers increased aperture of stomata without affecting their frequency and size. Segura (1989) found in arabica seedlings that urea sprays increased $E$, presumably due to increased $g_{\mathrm{s}}$, which was accompanied by a reduction in $\Psi_{\mathrm{w}}$. Tesha and Kumar (1978), from field experiments with arabica coffee conducted in Kenya, showed that $E$ at the leaf level increased with increasing $\mathrm{N}$ status under an adequate water supply, and decreased markedly as soil water became less available. Such behaviour obviously is of particular interest in relation to coffee cropping since 
it would allow minimization of water loss under drought while maximizing carbon gain at the expense of water loss under high soil moisture. However, in potted robusta coffee $\mathrm{N}$ supply did not affect the stomatal behaviour, regardless of the leaf water status (DaMatta et al., 2002a,b). In contrast, N application brought about an increased cell-wall rigidity and osmotic adjustment upon discontinuing watering (DaMatta et al., 2002a). Thus, the effects of $\mathrm{N}$ supply on drought tolerance of robusta coffee plants might be more directly related to an increasing ability for water uptake instead of a decreasing water loss through stomatal control.

Stomatal control of $E$ may decrease substantially as the scale increases from leaf to canopy. As the leaf transpires, water vapour tends to humidify the air nearby the leaves, thus decreasing the boundary layer conductance $\left(g_{\mathrm{b}}\right)$ surrounding each leaf and uncoupling the vapour pressure at the leaf surface from that of the bulk air (Jarvis and McNaughton, 1986). When plant canopy is poorly coupled to the atmosphere, i.e. when the canopy $g_{\mathrm{b}}$ is small as in high-density plantings or as a result of factors such as low windspeed, $E$ becomes much more dependent on solar radiation than on $D$. In contrast, when the plant canopy is well coupled to the atmosphere, as occurs in hedges with large inter-row spaces, the ratio of $g_{\mathrm{s}}$ to $g_{\mathrm{b}}$ decreases, and then $E$ becomes more sensitive to $g_{\mathrm{s}}$ and $D$ (DaMatta, 2003). Jarvis and McNaughton (1986) described quantitatively the sensitivity of leaf or canopy $E$ to a marginal change in $g_{\text {s }}$ using a decoupling factor, $\Omega$

\section{$\Omega=(e+1) /\left(e+1+g_{\mathrm{b}} / g_{\mathrm{s}}\right)$}

in which $e$ is the increase in latent heat content of the air per increase of sensible heat content of saturated air. Values for $\Omega$ range from zero to unity: as $\Omega$ approaches 1, stomatal control of $E$ declines progressively. Of course, values of $\Omega$ tend to decrease when $g_{\mathrm{s}}$ is dropped by drought or afternoon reduction in stomatal aperture, and to increase as $g_{\mathrm{s}}$ increases as well.

Within arabica and robusta coffee, there are large genotypic differences in crown morphology and total leaf surface area per plant. Because leaf size and density are related to $g_{b}$ and aerodynamic roughness, hydraulic architectural traits of coffee genotypes are expected to vary accordingly. Tausend et al. (2000b) compared three arabica coffee cultivars with contrasting growth habits and crown architectures and showed that regulation of $E$ (as measured by the sap flow technique) was governed by divergent hydraulic architecture rather than stomatal physiology. On a daily basis, maximum total whole-plant $E$ was $13 \mathrm{~kg}$ in cv. Typica with the most open crown $\left(\Omega=0.38 ; 22.9 \pm 1.7 \mathrm{~m}^{2}\right.$ leaf area $)$, against $8 \mathrm{~kg}$ in cv. Yellow Caturra with the shortest and dense crown $(\Omega$ $=0.56 ; 27.5 \pm 3.3 \mathrm{~m}^{2}$ leaf area). This corroborates some empirical observations that dwarf cultivars with dense crowns (larger $\Omega$ ) are better able to postpone dehydration than cultivars with open crowns, regardless, within given limits, of their leaf areas (DaMatta, 2004b). Interestingly, Tausend et al. (2000b) observed that $E$ remained nearly constant in all cultivars examined following $40 \%$ defoliation. They found weak correlations of $E$ and crown conductance with $\Psi_{\mathrm{w}}$, but strong correlations of those variables with total hydraulic conductance of the soil-leaf pathway $\left(G_{\mathrm{t}}\right)$, suggesting that $E$ may be limited by $G_{\mathrm{t}}$. This behaviour was independent of $g_{\mathrm{s}}$, which did not increase significantly, and therefore a compensatory increase in leaf-level $E$ should have occurred as a consequence of increased coupling between the canopy and the atmosphere. This finding has practical implications for managing irrigation in pruned orchards, because it cannot be assumed that whole-plant water requirements would be reduced in proportion to the leaf area removed (Tausend et al., 2000b). The above considerations well illustrate the assertion of Jones (1998) that "plant physiologists, in general, have tended to overestimate the control exerted by stomata on $E$ as a result of ignoring the canopy and regional boundary layers, thus they have tended to underestimate $\Omega$ ". Nevertheless, the importance of stomatal control on water loss clearly increases with increasing plant water deficit.

The strong association of total $E$ with $G_{\mathrm{t}}$ suggests that coffee cultivars with lower $G_{\mathrm{t}}$ should deplete accessible soil water more sparingly when it is readily available, thus retaining more water in the soil profile for longer periods. In contrast, higher $G_{\mathrm{t}}$ might attenuate variation in $\Psi_{\mathrm{w}}$ with variation in water availability, which may help to avoid nonstomatal limitation to photosynthesis and xylem cavitation (Tausend et al., 2000a), in addition to maintaining a high internal hydrostatic pressure allowing growth. A higher $G_{\mathrm{t}}$ has also been associated with greater biomass accumulation, as observed in unstressed clones of robusta coffee (Pinheiro et al., 2005). On the other hand, higher $G_{\mathrm{t}}$ would be disadvantageous with long-term soil drying, since it would hasten the development of severe plant water deficit, but advantageous with a non-limiting water supply or with brief soil water shortages. Hence, cultivars with higher $G_{\mathrm{t}}$ and less responsive to changes in $D$ should be targeted to regions with no prolonged droughts or, alternatively, to cultivation with supplemental irrigation. 
Water use can be usefully expressed through the crop coefficient $\left(K_{\mathrm{c}}\right)$, a ratio between $E T_{\mathrm{c}}$ and the reference evapotranspiration $\left(E T_{0}\right)$. Maximum values of $K_{\mathrm{c}}$ varied between 0.59 (for a leaf area index, $\mathrm{LAI}=1.4$ ) and $c a \cdot 0.80$ (for a LAI $=5.4-6.7$ ), as estimated in an irrigated coffee (cv. Yellow Catuaí) plantation in a hedgerow configuration carried out in Hawaii by Gutiérrez and Meinzer (1994a). They showed that crop $E$ became an increasingly important component of $E T_{\mathrm{c}}$ as the canopy develops, reaching 95 $\%$ of $E T_{\mathrm{c}}$ at a $\mathrm{LAI}=6.7$. In contrast, soil temperature (i.e., within-row advection) played a predominant role at early stages of canopy development. Regardless of LAI, temporal changes in $E T_{\mathrm{c}}$ in well-watered coffee plants do not necessarily accompany changes in $E T_{0}$, so it is common that a seasonal reduction in $K_{\mathrm{c}}$, and thus in water use, may occur independently of seasonal changes in evaporative demand. This response appears to be a consequence of the efficient stomatal closure as the air becomes drier. After withholding irrigation, $K_{\mathrm{c}}$ began to decline shortly ( $c a .5$ days), halving in value from 0.8 to 0.4 after 18 days. This seemed to be entirely traceable to continuous reduction in $E$ (normalized by net solar radiation) that began before any detectable reduction in $\Psi_{\mathrm{w}}$, suggesting a stomatal limitation to $E$ (Gutiérrez and Meinzer, 1994a). In a companion study, Gutiérrez and Meinzer (1994b) showed that withholding irrigation remarkably influenced the energy balance of the coffee crop, strongly increasing the Bowen ratio (the ratio of sensible to latent heat loss) from 0.3 in well-irrigated plants to 1.4 after imposing a drying cycle for 23 days, indicating that the largest proportion of net radiation was dissipated as sensible heat with rising plant water deficit. However, a rapid recovery of all energy balance components to their previous values was found upon resuming irrigation. Taken together, these considerations reinforce the importance of stomatal behaviour in controlling the water use of coffee, particularly under soil and atmospheric water deficit.

Vulnerability of the xylem to cavitation appears at first glance to be high in coffee. Tausend et al. (2000a), from a study with excised branches of three arabica coffee cultivars, showed that for $\Psi_{\mathrm{w}}=-2.5 \mathrm{MPa}$, hydraulic conductivity decreased between 29 and $50 \%$, depending on cultivar. According to these authors, the loss of hydraulic conductivity at relatively high values of $\Psi_{\mathrm{w}}$ could be interpreted as a low tolerance to drought, and could be related to the relatively mild conditions in the understorey in which arabica coffee evolved. On the other hand, even at the lowest $\Psi_{\mathrm{w}}$ measured (ca. $-6.5 \mathrm{MPa}$ ), substantial hydraulic conductivity, ranging from 20 to $40 \%$, remained in all cultivars examined. Furthermore, the rapid recovery of $G_{\mathrm{t}}$ following a fall of rain suggests that loss of xylem hydraulic conductivity at low $\Psi_{\mathrm{w}}$ may be largely reversible in coffee (Tausend et al., 2000a). Such information lends some support to explain why in strongly drought-stressed (predawn $\Psi_{\mathrm{w}}<-4.0 \mathrm{MPa}$ ) plants of robusta coffee, both under field and pot conditions, leaf water status rapidly recovers (1-2 days) to control levels upon re-watering (DaMatta, unpublished results). Taken together, these results appear to be of paramount importance in determining the fast recovery of coffee growth and canopy development after prolonged drought events (6-7 months) when the soil is re-wetted by rain, as empirically observed in marginal lands in southeastern Brazil.

\section{Photosynthesis and crop yield}

The identification of a threshold at which $A$ begins to decline due to water limitation is of great relevance, since it will define a range of soil and plant water status that would likely result in large reductions in biological productivity. Such a threshold was suggested to be close to $\Psi_{\mathrm{w}}$ of -1.0 MPa for potted arabica coffee growing in drying soil (Kumar and Tieszen, 1980b). However, in most studies with potted coffee, $A$ has been shown to decrease curvilinearly with decreasing $\Psi_{\mathrm{w}}$ (e.g., Kanechi et al., 1988, 1995b; Pinheiro and DaMatta, unpublished results), with no clear $\Psi_{\mathrm{w}}$ setpoint to cause a reduction in $A$. This emphasizes the difficulty to establish a precise $\Psi_{\mathrm{w}}$ at which photosynthesis begins decreasing due to genotype variability, growth conditions, rate of stress progression and interference of environmental conditions during which measurements are conducted (DaMatta, 2003). In effect, Almeida and Maestri (1997), from a pot experiment with four arabica coffee cultivars, reported exponential decreases $\left(r^{2}=0.99\right)$ in photosynthetic capacity $\left(A_{\text {max }}\right)$ which started to occur even at predawn $\Psi_{\mathrm{w}}$ as high as $-0.5 \mathrm{MPa}$. As photosynthesis was assessed under presumably saturating $\mathrm{CO}_{2}(5 \mathrm{kPa})$, direct effects of water deficit on the photosynthetic reactions at the chloroplast level must have taken place. These results are difficult to reconcile with field experiments in which $A$ (expressed on a leaf area basis) measured throughout the morning were maintained at control levels with predawn $\Psi_{\mathrm{w}}$ as low as $-1.5 \mathrm{MPa}$ (DaMatta et al., 2003).

In potted $C$. arabica cv. Typica, $A$ decreased curvilinearly with rising $D$ (from 0.2 to about $1.7 \mathrm{kPa}$ ) (Fanjul et al., 1985), while in C. arabica cv. Arabigo it remained relatively unchanged as the leaf-to-air $D$ increased from 0.5 to $1.5 \mathrm{kPa}$, 
but declined almost linearly for higher $D$ values (Hernández et al., 1989). In both situations, the effects of $D$ on $g_{\mathrm{s}}$ were stronger than on $A$. This has been explained in terms of the additional resistances associated with $\mathrm{CO}_{2}$ flux into leaves, so partial closure of stomata does not necessarily decrease the $\mathrm{CO}_{2}$ influx to the point of impairing photosynthesis. As stomata close further, less $\mathrm{CO}_{2}$ flows into the leaves so that stomatal limitations to photosynthesis then arise (DaMatta, 2003).

At the leaf level, in many species, including coffee (e.g., Fanjul et al., 1985; Meinzer et al., 1990b, 1992), $g_{\mathrm{s}}$ is strongly correlated with $A$. The sensitivity, quite marked in some instances, of $g_{\mathrm{s}}$ to predawn $\Psi_{\mathrm{w}}$ and $D$ (e.g., Pinheiro et al., 2005) suggests that $g_{\mathrm{s}}$ is a key factor limiting crop yield in coffee. As reasoned by DaMatta (2003), in short-term soil drought, yield reduction could be related to reduced $g_{\mathrm{s}}$ and concomitantly lower $A$, but in the long-term, a smaller leaf area and an altered assimilate partitioning between plant structures and organs could be more directly responsible for decreased crop yield. The smaller leaf area (due to decreased leaf size and production, and higher rates of leaf senescence), as has been found in both pot- and field-grown coffee plants (Meinzer et al., 1992; DaMatta et al., 2003), should lead to a decreased $\Omega$. Additional reductions in $g_{\mathrm{s}}$ are to be expected and, as a consequence, stomatal limitations to photosynthesis should be exacerbated with the progression of drought, thus further contributing to limit crop yield. Under moderate water-deficit conditions, decreases in leaf area are not necessarily accompanied by decreases in $A$ on a leaf area basis, but if drought progresses further, strong decreases in $A$ per unit leaf area may also be observed (Meinzer et al., 1992). Whatever the case, interpretation of short-term gas-exchange measurements in leaves with this form of phenotypic adjustment to resource limitation may be problematic if the total leaf area of each tree is not considered, as highlighted elsewhere (DaMatta, 2004b).

Under severe drought conditions, non-stomatal inhibition to photosynthesis certainly becomes important (DaMatta et al., 1997a). However, severity of drought is intimately related to the rate of stress progression, that is, the fast the rate is, the lower the ability for the plant to acclimate to drought, which would increase stress-induced imbalances at the chloroplast level [e.g., compare data from Lima et al. (2002) with those from Pinheiro et al. (2004)]. In coffee, such imbalances are unlikely to be associated with PSII photochemical efficiency since the variable to maximum fluorescence ratio is remarkably stable under drought
(Almeida and Maestri, 1996; DaMatta et al., 1997a, 2002; Lima et al., 2002; Pinheiro et al., 2004; Praxedes et al., 2005), or with decreased concentration of photosynthetic pigments (Almeida and Maestri, 1996; Kanechi et al., 1996; DaMatta et al., 1997a), but may involve decreases in carboxylation function (Kanechi et al., 1996). Under rapidly imposed water deficit $\left(\Psi_{\mathrm{w}}=-3.0 \mathrm{MPa}\right)$, initial activity of rubisco, but not its concentration, decreased by $c a$. $60 \%$, but when water deficit was imposed slowly the concentration was also reduced (Kanechi et al., 1991).

Drought stress stimulates earlier leaf senescence, particularly in physiologically older leaves. In droughttolerant clones of robusta coffee grown in the field, this is not apparently associated with a rise in oxidative stress conditions since the extent of lipid peroxidation was similar in both irrigated and severely drought-stressed (predawn $\Psi_{\mathrm{w}}$ below -4.0 MPa) clones (Pinheiro and DaMatta, unpublished results). Leaf abscission may be considered as a whole-plant mechanism to limit $E$, but at least in drought-sensitive clones of robusta coffee, which lose considerable amounts of their foliage, such a strategy was not efficient enough, since the water status in the remaining leaves was severely impaired (DaMatta et al., 2000, 2003). Empirical evidence from field observations suggests that tolerant coffee cultivars delay or reduce drought-induced leaf shedding, thus saving resources that otherwise would be diverted into restoration of leaf area during the early rainy season. However, this is not necessarily beneficial to yield maintenance under drought if $g_{\mathrm{s}}$ remarkably decreases, provoking a strong limitation to gas exchanges, which would favour survival over yield maintenance. On the other hand, if $g_{\mathrm{s}}$ does not remarkably decrease, a sufficient $G_{\mathrm{t}}$ associated with deep roots compensating for excessive water loss becomes increasingly important, which would dampen variation in shoot water status, allowing crop productivity to be maintained. DaMatta et al. (2003), for example, found that the better crop yield of a drought-tolerant clone of robusta coffee, compared with a drought-sensitive one, was associated with maintenance of leaf area and higher $\Psi_{\mathrm{w}}$, as a consequence of increased wateruse efficiency and deeper roots.

The relationship among gas exchange, plant water status and carbon isotope discrimination $(\Delta)$ has been examined in some coffee genotypes (Meinzer et al., 1990a; DaMatta et al., 2000, 2003; Pinheiro et al., 2005). Working with five fieldgrown genotypes of arabica coffee, Meinzer et al. (1990a) pointed out that a higher long-term water-use efficiency [lower $\Delta$; see Farquhar et al. (1989) for a review] under 
adequate irrigation resulted from decreased $g_{\mathrm{s}}$ rather than increased $A$ at a given $g_{\text {s }}$. They also showed that genotypes with higher $\Delta$ under full irrigation depleted soil water faster and experienced symptoms of physiological stress earlier when water was withheld, thus suggesting that $\Delta$ of wellwatered coffee plants could be used to predict genotype water-use performance under drought conditions. However, it should be pointed out that this study was not large enough to demonstrate conclusively the usefulness of $\Delta$ as an index for ranking coffee genotypes in terms of drought tolerance. Results from Meinzer et al. (1991), revealing a positive correlation between $\Delta$ and coffee yields, emphasize the need for expanding such studies using a larger number of genotypes. Nonetheless, such a positive correlation means that low $\Delta$ would be related to lower productivity in environments with non-limiting water supply on one hand, and to some stability of coffee yields in drought-prone environments on the other hand.

\section{Carbon and nitrogen metabolism}

Under drought, changes in carbohydrate pools should reflect genotypic differences in the regulation/acclimation of carbon metabolism at the whole plant level, as reviewed elsewhere (e.g., Chaves, 1991; Lawlor, 2002; Lawlor and Cornic, 2002).

In coffee, studies of carbohydrate metabolism under water-deficit conditions are very scarce. Some investigations have shown that a drop in starch concentration is a general response of the coffee plant to severe or even mild water deficit (DaMatta et al., 1997a; Praxedes et al., 2005; Ronchi et al., 2005). This is not necessarily accompanied by increased soluble sugar contents, which depends on genotype, growth conditions and rate of stress progression (Ronchi et al., 2005), as also noted for other plant species (Chaves, 1991). Praxedes et al. (2005), in a pot study with a slow imposition of drought stress (predawn $\Psi_{\mathrm{w}}=-3.0 \mathrm{MPa}$ ), found in three of the four robusta clones examined a decrease in sucrose synthesis, attributed to an inhibition of sucrose-phosphate synthase activity and activation state. This decline was concomitant with a rise in sucrose degradation, associated with increased acid invertase. However, sucrose content did not decline with increasing leaf water deficit, so Praxedes and coworkers proposed that assimilate export was reduced owing to a decreased sink demand. In the other clone (clone 120), classified as drought-tolerant based on its ability to maintain crop yield under drought conditions, both sucrose-phosphate synthase activity and activation state were maintained, and acid invertase and fructose-1,6-bisphosphatase activities increased, paralleling a rise of sucrose and hexose contents. Such drought-induced accumulation of soluble sugars (and also amino acids) could contribute to osmotic adjustment in this clone. The authors also suggested that sucrose-phosphate synthase activity might be associated with assimilate export, which might support some additional root growth in droughtstressed plants. These responses could help the clone 120 in keeping its productivity in drought-prone areas, contrarily to what is observed with the other three clones examined.

Compared with carbohydrate metabolism, much less is known about nitrogen metabolism in drought-stressed coffee plants. Meguro and Magalhães (1983) in Brazil observed in five potted arabica cultivars linear decreases in nitrate reductase activity as leaf $\Psi_{\mathrm{w}}$ decreased from $c a$. -1.0 to -3.0 $\mathrm{MPa}$. The slope of the relationship between enzyme activity and $\Psi_{\mathrm{w}}$ was significantly steeper for cv. Nacional (Typica) than for cv. Catuaí, the former identified as less tolerant of drought than the latter. Arabica coffee trees may perform nitrate reduction in both leaves and roots (Carelli and Fahl, 1991; DaMatta et al., 1999), but such ability is lost in aerial parts during much of the dry, cool season, as found in Viçosa, Brazil (650m a.s.1., 204' $\mathrm{S})$. However, this behaviour is apparently unrelated to soil drought, but directly associated with a low temperature effect on the activity of nitrate reductase (DaMatta et al., 1999).

It should be stressed that an adequate $\mathrm{N}$ supply could indirectly improve tolerance to drought, since it will allow the triggering of chloroplast photoprotection mechanisms and membrane qualitative changes under excessive excitation energy (Ramalho et al., 1998, 1999, 2000), which occur when stomata closure is promoted by water shortage.

\section{Root characteristics}

Root characteristics and growth play a crucial role in maintaining the water supply to the plant, and droughtadapted plants are often characterized by deep and vigorous root systems. However, predicting the best rooting strategy for a particular crop will depend on the characteristics of the crop's seasonal demand for water, soil depth and chemical and physical properties, as well as the seasonal rainfall distribution. Thus, to breed for a large root system to exploit as much of the soil for water as possible is not necessarily the best option. With this strategy, resources could be diverted unnecessarily into roots exploiting surface dry soil and more assimilates going into root growth could compromise reproductive growth (Quarrie et al., 1999). Nevertheless, 
Ramos and Carvalho (1997), working with 29 coffee genotypes, have associated drought tolerance with a larger root dry mass, which should be related to root distribution and structure, and not quantity, in the determination of the most efficient strategy for extracting water during drought periods. Indeed, drought postponement in clones of robusta coffee has been associated with deeper, but not necessarily larger (dry mass), root systems (Pinheiro et al., 2005).

The root resistance to water transport in the soil-plant pathway seems to be greater in arabica coffee than in $C$. canephora cv. Apoatã (Brunini and Angelocci, 1998; Fahl et al., 2001). Although a contentious issue (see Rena and DaMatta, 2002), Apoatã also appears to have a much more developed root system than arabica cultivars (Ramos and Lima, 1980), which would enable it to increase access to soil water and, as a consequence, to maintain a favourable internal water status. Indeed, C. arabica cv. Catuaí grafted onto Apoatã showed considerable increases in root to shoot ratio (Fahl et al., 1998) in addition to having remarkably greater gas-exchange rates than the non-grafted Catuaí plants (e.g., $g_{\mathrm{s}}$ was almost three times larger in both grafted Catuai and non-grafted Apoatã), as shown by Fahl et al. (2001) in field experiments conducted during the dry season in Brazil.

\section{Drought tolerance}

The native home of coffee species is characterized by low-water-deficit conditions, which probably allowed evolution without the need to develop extensive mechanisms to cope with drought stress (Coste, 1992; Rena et al., 1994). Nevertheless, some coffee cultivars are known to differ in their responses to drought (Orozco-C and Jaramillo-R, 1978; Carr, 2001; DaMatta and Rena, 2001), suggesting that modern cultivars are not very close to their wild relatives in terms of drought tolerance. In fact, field observations have indicated that some cultivars may endure 6-7 months with no rain, even in sandy soils, but obviously at the expense of strong declines in crop yield (DaMatta, unpublished observations).

Within C. canephora, extensive observations have indicated that Kouillou endures drought stress much better than Robusta (Boyer, 1965; Coste, 1992). This is likely to be associated with a presumably higher stomatal sensitivity to both soil and atmospheric droughts in the former (DaMatta and Rena, 2001). In Brazil, there seems to be a generalized idea that Kouillou is more tolerant to drought than arabica cultivars. However, due to the wide polymorphism existing within Kouillou, as in C. canephora as a whole, any generalization about the subject can be misleading and should take into account some conflicting information about the relative abilities for better drought endurance in arabica and robusta coffee cultivars (e.g., Nunes, 1976; Orozco-C and Jaramillo-R, 1978). Indeed, the available information seems to indicate that, in terms of performance under drought, the best genotypes of these two species exhibit similar degrees of drought tolerance (DaMatta and Rena, 2001).

Species or cultivars more tolerant to drought generally differ morphologically and/or physiologically, with mechanisms allowing greater production under restricted water supply. Understanding such mechanisms in genotypes naturally adapted to drought could help to improve their agronomic performance. In coffee, some physiological traits have been shown to potentially contribute to yield under drought conditions (DaMatta, 2004b), but the development of an efficient breeding method for drought tolerance is still a long-standing objective. A major component of differential adaptation to drought among arabica and robusta coffee genotypes appears to be behavioural, and may be governed by rates of water use and/or efficiency of extraction of soil water (Meinzer et al., 1990b; DaMatta et al., 2003; Pinheiro et al., 2005). In this context, comparative studies, both under pot and field conditions, have evidenced that drought-tolerant coffee genotypes are better able to maintain higher $\Psi_{\mathrm{w}}$ and/or RWC than drought-sensitive ones under water-deficit conditions (Boyer, 1965; Nunes, 1976; Josis et al., 1983; Renard and Karamaga, 1984; Meinzer et al., 1990b; DaMatta et al., 2000, 2003; Pinheiro et al., 2005; Praxedes et al., 2005). This characterizes a strategy of dehydration postponement, and could largely explain why drought-tolerant cultivars show later leaf wilting and shedding than drought-sensitive ones, as found in field trials conducted in Colombia with 25 cultivars of arabica and robusta coffee (Orozco-C. and Jaramillo-R., 1978). However, maintenance of a favourable water balance has been associated, in most cases, with survival rather than productivity under drought. Hence, if higher internal water status is chiefly associated with an efficient stomatal control of water loss, both $\mathrm{CO}_{2}$ uptake and crop yield are expected to be depressed. Therefore, selection of cultivars showing an early stomatal closure during drought should be promoted for rain-fed (particularly for environments with prolonged drought periods) but not for irrigated coffee production systems. That would improve survival and would allow small, but with low year-to-year variation of, crop yields under drought. In contrast, if higher internal water status is mainly associated with an efficient ability for water uptake, then selection of cultivars with stomata less responsive to both soil 
and atmospheric droughts is the best option, provided that the dry season is short or adequate irrigation is supplemented.

Coffee cultivars that could withstand severe drought spells with acceptable yields under water deficit should be the first requirement for a successful breeding programme for drought tolerance. With regard to robusta coffee, plant breeders have empirically selected some promising clones with the above quoted performance. Physiological evaluations of some of these clones have suggested that keeping an adequate water status (through a combination of deep rooting and satisfactory stomatal control of $E$ ), maintenance of leaf area (DaMatta et al., 2003; Pinheiro et al., 2005), and steep leaf inclinations (Pinheiro and DaMatta, unpublished results), as well as biochemical traits, are of utmost importance. The latter involve, e.g., improved tolerance of oxidative stress (Lima et al., 2002; Pinheiro et al., 2004) and ability for maintaining assimilate export (Praxedes et al., 2005). Such traits do not appear to be welldeveloped in drought-tolerant clones which favour survival over productivity under drought conditions. Taken together, these results suggest that no single trait is a sufficient predictor of drought tolerance in coffee, in terms of yield maintenance in water-limited environments. Combining traits associated with a favourable water status for longer and suitable biochemical characteristics, which enable some degree of tissue tolerance to desiccation, should improve coffee yields over a range of drought conditions.

\section{RESPONSES TO TEMPERATURE STRESS}

Extreme temperatures, depending on their intensity, duration and speed of imposition, impair cell metabolic processes (e.g., photosynthesis), growth and survival of plants, as well as their economic exploitation. As for any other plant species, coffee displays a diversity of acclimation mechanisms to avoid and endure these environmental constraints (as well as the oxidative stress usually promoted by them), developed within the genetic bounds of the plant/species. The efficiency of these mechanisms will determine the ability to cope with such environmental conditions, thus setting limits to species/genotypes distribution. In fact, temperature may limit the successful economic exploitation of the coffee crop, in part because coffee growth is particularly affected by both high and low temperatures (Barros et al., 1997; Silva et al., 2004).

\section{Low Positive Temperature Stress}

Low positive temperatures, known as chilling, has an overall negative impact on plant productivity due to the reduction of cell chemical and enzymatic reactions, diffusion rates of molecules and membrane fluidity. Among the cell structures, the chloroplast is usually the one that is more rapidly and deeply affected (Wise and Naylor, 1987; Kratsch and Wise, 2000; Mano, 2002). In fact, in chilling-sensitive plants, such as coffee, which exhibit (at least in their origin) limited ability to cope with cold, net photosynthesis ceases almost completely at 5-10 ${ }^{\circ} \mathrm{C}$ (Larcher, 1981). As for other plant species, such limitations could be attributed to reductions of $g_{\mathrm{s}}$, degradation of pigment complexes and loss of photochemical efficiency, increase of damage and reduction of repair processes at the PSI and PSII level (e.g., in D1 protein), restrictions of electron transport, enzyme activity, and carbohydrate metabolism, and increase of chloroplast membrane permeability (Larcher, 1981; Krause, 1994; Adams and Demmig-Adams, 1995; Morcuende et al., 1996; Haldimann, 1998; Allen and Ort, 2001). Furthermore, the exposure to chilling for several days might provoke significant after-effects upon rewarming, since $\mathrm{CO}_{2}$ uptake remains low or completely inhibited (Larcher, 1981).

Due to such sensitivity, the acclimation of the photosynthetic apparatus to low temperatures is of particular importance to plant survival. Such cold-induced tolerance includes increases in enzyme activities (e.g., from the Calvin cycle and sugar metabolism), reinforcement of energy dissipation mechanisms and antioxidative molecules, qualitative and quantitative changes in lipid (e.g., level of FA saturation) and protein membrane composition, all protecting cell structures and keeping metabolic pathway regulation mechanisms, as reported for coffee (DaMatta et al., 1997b; Campos et al., 2003; Ramalho et al., 2003; Quartin et al., 2004). In addition, the maintenance of respiratory metabolism is also of great importance, since it allows the production of energy, reducing power and metabolic intermediates, necessary for repair processes that are increasingly important under chilling conditions. In cold-sensitive plants, respiration is strongly affected due to the inhibition of several enzymes, which leads to an exponential decline of respiratory rates with decreasing temperatures (Larcher, 1981).

Since coffee is cultivated in the intertropical area, cold might be seen as a less important theme of debate for this crop. However, due to growing climate instability and cultivation in marginal regions, as well as to the known chilling sensitivity of arabica and robusta coffee, cold (both positive and negative temperatures) has become an increasingly important issue. Low positive temperatures often occur in production areas resulting in a depressing 
effect on growth, photosynthetic performance and yields (Bauer et al., 1985; DaMatta et al., 1997b; Ramalho et al., 2003; DaMatta, 2004a). Also, low air temperature plays a key role in controlling seasonal growth, as occurs in southeastern Brazil (Barros et al., 1997; Silva et al., 2004). In addition, low temperatures have strongly contributed to the loss of significant areas of cultivation in Paraná State in Brazil (that suffered a $60 \%$ decrease from 1970 to 1990), thus turning this subject an important matter of study and justifying the existence of specific breeding programmes for cold tolerance, e.g., as that of the Agronomic Institute of Paraná State, Brazil.

Despite the impact observed immediately after a sudden submission to cold, the exposure to chilling temperatures during a rather long period may promote the acclimation of coffee plants to cold (Quartin et al., 2004). This presumably occurs through the development of cold hardiness, a process involving a wide range of complex morphological, metabolic and ultrastructural changes (Hällgreen and Öquist, 1990; Gray et al., 1997; Kratsch and Wise, 2000), most of which, controlled through changes in the expression of coldregulated genes. As for other plants, the sensitivity of coffee to chilling and the severity of damage varies seasonally along the year (DaMatta et al., 1999; Silva et al., 2004), due to nutrient conditions and due to the intensity, duration and speed of imposition of low temperatures (Quartin et al., 2004), since a simple cold shock will not allow for an effective acclimation. Furthermore, the sensitivity differs among genotypes, phenological stages, tissues, organs and metabolic pathways of the same plant, bearing in mind that in younger coffee plants, growth processes, translocation of photosynthates and the photosynthetic metabolism are particularly sensitive (Bauer et al., 1985, 1990; Larcher, 1995; Ramalho et al., 2003).

Low positive temperatures may cause lethal damage. The most susceptible above-ground parts of young arabica coffee plants are the stem base (severely affected after $36 \mathrm{~h}$ at $1^{\circ} \mathrm{C}$ ), followed by older leaves (with severe necrosis), shoot meristematic cells and seed embryos. Among the stem tissues the cambial zone is the most sensitive presenting $100 \%$ injury after $96 \mathrm{~h}$ at $1^{\circ} \mathrm{C}$ (Bodner and Larcher, 1987; Larcher, 1995). Roots are also particularly sensitive since they are not usually exposed to low temperatures. The effects are related to lipoperoxidation of membranes and loss of selectivity that provoke a decrease in its fluidity and functionality (Alonso et al., 1997; Queiroz et al., 1998). The effects are even more severe when cold occurs after a period of high temperature (due to the lack of an acclimation period) or if other stresses are superimposed, especially under high irradiance (IBC, 1985; Willson, 1985).

In coffee, low positive temperatures are very harmful to photosynthetic structures, especially if $3-4^{\circ} \mathrm{C}$ (or lower) values are reached, which will provoke chl loss (mostly in leaf margins) and leaf necrosis (Bauer et al., 1990; Coste, 1992), as well as strong increases in leaf hydraulic conductance due to membrane damage (Gascó et al., 2004). Photosynthetic metabolism is strongly affected by chilling due to stomatal and non-stomatal limitations. The latter include impairments in electron transport rate, rubisco activity and ribulose-1,5bisphosphate (RuBP) synthesis, translocation of sugars and chloroplast membrane selectivity (Bauer et al., 1985; DaMatta et al., 1997b; Campos et al., 2003; Ramalho et al., 2003). In effect, the $A$ values reach less than half of the control value with an exposure of $12 \mathrm{~h}$ at $4^{\circ} \mathrm{C}$ (Bauer et al., 1985; Ramalho et al., 2003) and become negligible with longer exposures to $4^{\circ} \mathrm{C}$ or when shortly exposed to $0.5^{\circ} \mathrm{C}$, when significant necrosis is observed (Bauer et al., 1985; Ramalho et al., 2003). The decreased $A$ under chilling conditions brings about an excess of excitation energy that is delivered to the photosynthetic machinery, which causes photooxidation of chloroplast components, which in turn will further impair photosynthesis and will promote photoinhibition. Although $A$ in some cold-affected leaves may significantly recover, e.g., reaching control values after 6 days in some coffee plants (Bauer et al., 1985; Ramalho et al., 2003), a much slower recovery of photosynthesis is the general pattern of response, especially if leaf necrosis and senescence occur, thus having a high potential to provoke significant economic losses (Androcioli Filho et al., 1986). Moreover, the leaves produced under cold conditions are smaller, frequently distort, yellowish with extended necrosis, in addition to having a higher tendency to shed.

The sensitivity of coffee's vegetative growth is particularly evident when monthly mean temperatures drop below $15-16^{\circ} \mathrm{C}$ (Barros et al., 1999; Silva et al., 2004). The decline in growth might be due to direct effects of temperature or indirect through the negative impact on photosynthesis, assimilate storage and partitioning, respiration, leaf nitrogen assimilation, hormonal balance and other processes (Barros et al., 1997; Vaast et al., 1998; DaMatta et al., 1999; Guimarães et al., 2002; Ramalho et al., 2003). However, despite growth depression being apparently related to the reported decreases in $A$ at $13-17^{\circ} \mathrm{C}$ and below, as observed in some potted coffee genotypes (Ramalho et al., 2003), Silva et al. (2004), 
from a field study with arabica coffee trees, pointed out that depressions in both growth and photosynthesis would have simply run in parallel, rather than being related to each other. In any case, nitrogen assimilation and de novo protein synthesis would be strongly affected by low temperatures since nitrate reductase activity is dramatically affected (DaMatta et al., 1999), due to a direct thermal effect on the enzyme or due to a lack of substrate, since nitrate uptake is severely depressed (Vaast et al., 1998).

Despite some reports showing a higher cold sensitivity of arabica coffee (cv. Catuaí) than that of robusta coffee (DaMatta et al., 1997b), the latter is usually less able to acclimate to cold than arabica (Guimarães et al., 2002; DaMatta, 2004a). That agrees with observations that $C$. canephora cv. Apoatã (as well as $C$. dewevrei) shows significant decreases in $A, g_{s}$, quantum yield of linear electron transport rate, and PSII efficiency under photosynthetic steady-state conditions below $19 / 14^{\circ} \mathrm{C}$ (day/night), when compared with arabica coffee (Quartin et al., 1998; Ramalho et al., 2003). In fact, robusta coffee may occasionally endure temperatures below $7^{\circ} \mathrm{C}$, but problems often arise between $8-10^{\circ} \mathrm{C}$ and long periods at $15^{\circ} \mathrm{C}$ are already quite harmful. Furthermore, fruits and leaves are severely affected (with photobleaching and burns) below $5-6^{\circ} \mathrm{C}$ (Willson, 1985; Wrigley, 1988; Coste, 1992). Nonetheless, in both Catuaí and Apoatã, a high rate of leaf shed may occur 6-10 days after the end of the cold exposure in leaves that appear to be healthy and without discoloration symptoms (Bodner and Larcher, 1987; Ramalho et al., 2003).

Recent work performed with $C$. arabica cv. Catuaí, $C$. canephora cv. Apoatã, $C$. dewevrei and some interspecific hybrids (Campos et al., 2003; Ramalho et al., 2003) reported the existence of significant differences in cold sensitivity and acclimation ability, thus suggesting some genetic variability that could be exploited in breeding programmes. These studies implemented a quite long and progressive temperature decline before the exposure to chilling, giving the plants the opportunity to express differential acclimation abilities. Such studies include a large multidisciplinary analysis concerning the impact of chilling on the photosynthetic apparatus, sugar metabolism (photosynthesis and respiration), qualitative and quantitative changes of membrane lipids, membrane integrity and gene expression, always bearing in mind that control of oxidative stress is an essential feature to allow cold acclimation and tolerance. The results showed that the ability to cold acclimation relies on a complex network of responses, triggered mostly during the gradual cold imposition period, but also under chilling exposure. Net photosynthesis was strongly affected below $17 / 12^{\circ} \mathrm{C}$ (day/night), showing negligible values at $4^{\circ} \mathrm{C}$ in all the studied genotypes (Ramalho et al., 2003). However, the mesophyll impairments (and the ability to recover), which usually prevail over stomatal limitation at low temperatures (Ramalho et al., 2003; Silva et al., 2004), were quite different among the cultivars examined. Icatu presented the best performance (followed closely by cv. Catuaí) under cold exposure, confirming earlier field observations (Fazuoli et al., 1995), while $C$. dewevrei proved to be the most susceptible genotype. The higher susceptibility of $C$. dewevrei (and partially in Catuaí) could also be associated with leaf tissue dehydration that might have reached the turgor loss point (Quartin et al., 2000). Icatu maintained RWC values above the turgor loss point, had higher $A_{\max }$ values and thylakoid electron transport rates, especially at PSI, which has been described as a particular chilling sensitive target in some tropical plants (Sonoike, 1996). Icatu also presented an increased activity of key enzymes (malate dehydrogenase and pyruvate kinase) involved in respiratory sugar consumption (indispensable for the maintenance of cell metabolism and repair processes) and a stabilization of sugars, the latter being of utmost importance, since the restoration of the balance between photosynthesis, carbon metabolism and translocation is essential for the expression of a higher cold tolerance (Byrd et al., 1995; Leegood, 1995; Hurry et al., 1998; Allen and Ort, 2001; Ramalho et al., 2003).

Differential expression of genes triggered by cold in coffee has been observed, such as for some chitinases, lipoxygenase and methalothionein (which will help also to control oxidative stress) genes (Santos et al., 2004; Ramalho et al., 2003; Ramalho et al., unpublished results). Particular attention was paid to the accumulation of RNA transcripts for chitinase, since the accumulation of this protein in the plant apoplast and its antifreeze activity have been frequently reported (Yeh et al., 2000; Kasprzewska, 2003). Preliminary results show that the expression of chitinase genes (cachi3-1, cachi3-2 and cachi4-1) might play a role in the cold acclimation and tolerance processes, acting together or serving of support for the action of other genes (Santos et al., 2004). The accumulation of transcripts for all (Icatu) or two (Catuaí) of the studied chitinase genes suggests that these plants are preparing their cellular machinery for adverse conditions, including subzero temperatures. Coffea dewevrei was the only plant material that did not show positive changes in the expression of chitinase genes under cold exposure (despite 
the detection of some constitutive expression), which seems to lend some support for partially explaining its high cold sensitivity.

In conclusion, the tolerance to low positive temperatures relies on the maintenance of the balance in a complex network of mechanisms that allow the plants to down-regulate the photosynthetic metabolism at temperatures close to $0^{\circ} \mathrm{C}$ (Karpinski et al., 2002), concomitantly with the triggering of repair and protection mechanisms. In this way, during cold exposure, reversible impairments should dominate, the acclimation ability being supported by the reinforcement of key enzymes (e.g., rubisco, respiratory enzymes), promotion of adequate membrane lipid characteristics (e.g., low FA unsaturation) and, mostly, with the strengthening of antioxidative mechanisms (e.g., through increases in zeaxanthin, lutein, enzyme activities), all of them related to differential gene expression.

\section{Negative Temperature Stress}

Frost (negative temperatures) is even more damaging than chilling, and its occurrence, even sporadic, may strongly compromise the economic viability of the crop, since its impact includes destruction of leaves and fruits in arabica coffee in the year of occurrence, but also with yield repercussions during the following years (Androcioli Filho et al., 1986; Feio, 1991). Eventually, frosts can completely kill the coffee tree. Both arabica and robusta coffee are very sensitive to frost (Feio, 1991) and tolerant cultivars are still not known. However, some reports suggest the existence of differential sensitivity and survival ability among coffee genotypes (Androcioli Filho et al., 1986; Fazuoli et al., 1995; Sentelha et al., 1995; Sera and Guerreiro, 1998; Quartin et al., 2004). Furthermore, higher (indirect) tolerance to frost was observed in cultivars with lower sensitivity to leaf rust (Hemileia vastatrix), since the plant would be healthier (better vigour, nutritional status and leaf coverage) when frost occurs and would be less sensitive to pathogen attack after that occurrence, thus with smaller effects on whole plant and yield level (Sera and Guerreiro, 1998).

Despite coffee being sensitivity to frosts, if temperature decreases slowly some acclimation is observed, but the leaf lethal limit (related to ice formation) is reached at a minimum between $-3^{\circ} \mathrm{C}$ and $-5^{\circ} \mathrm{C}$ (Manetti and Caramori, 1986; Sentellhas et al., 1995; Guimarães et al., 2002; Quartin et al., 2004). At these values, strong cell dehydration is observed due to the formation of intercellular ice, which in turn will cause irreversible disruption of cell membranes, which is substantially different from what happens with low non-freezing temperatures (Guimarães et al., 2002; Gascó et al., 2004).

A link between increased tolerance to frosts and water deficit was pointed out by Caramori et al. (2002). They withheld irrigation and obtained a set of coffee seedlings with $\Psi_{\mathrm{w}}$ varying from -0.45 to $-4.8 \mathrm{MPa}$. When the seedlings were submitted to $-3^{\circ} \mathrm{C}$ for $90 \mathrm{~min}$, the authors observed leaf damage to a greater extent in well-irrigated plants $\left(\Psi_{\mathrm{w}}\right.$ above $-1.3 \mathrm{MPa}$ ). The magnitude of damage decreased with decreasing $\Psi_{\mathrm{w}}$ down to $-4.0 \mathrm{MPa}$, after which damage started to increase, possibly due to direct effects caused by severe leaf dehydration. Caramori et al. (2002) associated the increased tolerance to low negative temperature with a build-up of concentration of cell solution, as had already been suggested by Chaves and Manetti Filho (1990), who found that coffee seedlings fertilized with potassium under controlled conditions were less damaged by frost than unfertilized seedlings. These results suggest that when frosts occur under natural conditions, it can be expected that more severe damage will occur in well-hydrated coffee plants. Therefore, regional variability for damage extent after frost might in part be related to the degree of leaf hydration and, as a consequence, to the dilution of the cell solution.

Despite some success in the breeding for frost tolerance in coffee (Petek et al., 2000), genotypes with an effective acclimation to subzero temperatures are still to be obtained. That underlines the need to find other ways to reduce the impact of adverse climatic conditions, which may include suitable agronomic practices like the implementation of shaded conditions (see below).

\section{High Temperature Stress}

High temperatures are known to disturb plant metabolism, since reaction kinetics are accelerated, bonds within macromolecules are loosened and lipid layers from biomembranes became more fluid. Furthermore, high temperatures promote extensive denaturation and aggregation of cellular proteins, over-production of ROS and inhibition of normal transcription and translation. If stress is too strong (in intensity and/or duration), signalling pathways leading to apoptosis are also activated (Larcher, 1995; Krishna, 2004).

Most plants survive high temperatures through the prevention and mitigation of overheating (increased $E$, synthesis of reflective surfaces, paraheliotropic leaf movements, etc.) and due to the capacity of protoplasm to tolerate high temperatures (Larcher, 1995). As for cold, 
a common feature of the high temperature response is that an initial exposure to mild stress provides resistance against a subsequent usual lethal temperature. The process of hardening to heat (acquired thermotolerance) takes place in some cases in hours (e.g., along the day) or over extended periods (e.g., along seasons). An important contribution to enhanced survival ability is provided by molecular chaperones, such as heat-shock proteins, that prevent protein aggregation, stabilize chromatin and promote repair mechanisms (Larcher, 1995; Krishna, 2004).

Because thylakoid membranes are especially sensitive to heat, disturbances in photosynthesis are among the first indicators of stress. In fact, the uncoupling of electron transport and ATP synthesis is promoted, PSII and enzyme activities gradually decrease and chloroplast ultrastructure can be disrupted (e.g., by ROS action) (Larcher, 1995; Mano, 2002). Even moderately high temperatures may affect crop productivity, by changing the balance between respiration and photosynthesis, the latter being increased to a greater extent, and to inadequate storage capacity. Economic production often depends on the development of organs like leaves and fruits, which under excessive high temperatures can grow too fast in relation to the available photosynthetic resources, resulting, e.g., in small leaves and shrunken fruits (Lawlor, 2001).

Much classical work conducted from 1950 to the 1970s (e.g., Heath and Orchard, 1957; Wormer, 1965; Nunes et al., 1968; Bierhuizen et al., 1969; Cannell, 1976; Kumar and Tieszen, 1976, 1980a) suggested, although this was somewhat misleading, that coffee photosynthesis is particularly sensitive to temperatures above $20-25^{\circ} \mathrm{C}$. Indeed, Kumar and Tieszen (1976) reported that $A$ would be lower at $35^{\circ} \mathrm{C}$ than at $10^{\circ} \mathrm{C}$, while Nunes et al. (1968), using potted arabica plants, suggested that, for mature plants, above $24^{\circ} \mathrm{C}$ a drop of $10 \%$ in production of dry matter would occur for each $1^{\circ} \mathrm{C}$ rise, so that dry matter accumulation would approach zero at $34^{\circ} \mathrm{C}$. This response was associated with a presumably strong thermal effect on $A$, which was related to stomatal closure and/or mesophyll impairments, the latter being progressively increased at temperatures above $26^{\circ} \mathrm{C}$ (Nunes et al., 1973; Kumar and Tieszen, 1980a). Taken together, these studies pointed to dramatic thermal effects on the coffee plants, which, in fact, are not usually observed under field conditions. The reported effects on $A$ could be explained, at least partly, by the fact that high temperature stress was not studied in an isolated manner, thus allowing other limiting conditions to be superimposed, such as high irradiance or low air humidity. In addition, much of these classical studies were conducted with small pots under presumably controlled and constant conditions, which would obstruct the plant's acclimation to a changing environmental factor (DaMatta, 2004a). In fact, by rising temperatures gradually (from $24^{\circ} \mathrm{C}$ up to $33-35^{\circ} \mathrm{C}$ ) and considering a sufficiently long acclimation time, arabica plants were able to increase their $A$ up to temperatures around $30^{\circ} \mathrm{C}$, displaying the same efficiency as observed at $24^{\circ} \mathrm{C}$, even though dark respiration increased by $50 \%$ (see DaMatta, 2004a). Also, the temperature needed to obtain $A_{\max }$ was observed to be as high as $35^{\circ} \mathrm{C}$ for both arabica and robusta coffee (DaMatta et al., 2001). The maintenance of high photosynthetic efficiency suggests the absence of negative effects on the photosynthetic structures, which agrees to some extent with the absence of membrane permeability changes after a short-time exposure up to $50^{\circ} \mathrm{C}$, as found in arabica coffee by Gascó et al. (2004). Therefore, in our opinion, the coffee plant possesses a higher tolerance to elevated temperatures than most classical work seems to indicate. Otherwise, coffee productivity would be quite low in tropical environments, where leaf temperature easily reaches values above $30^{\circ} \mathrm{C}$ during a great part of the day, especially in the outer leaves of the canopy, as already noted by DaMatta (2004a). Furthermore, rates of both photosynthesis and vegetative growth of the coffee tree are maximal throughout the warm season, as occurs in the main Brazilian producing areas (Silva et al., 2004).

Coffee cultivation in the open is the usual practice in many parts of the world, and this provokes leaf exposure to high irradiance and the absorption of much more energy than that usable by photosynthesis. Such conditions may cause an energy overcharge and to an overheating of leaves that, in extreme cases, can reach temperatures of $40^{\circ} \mathrm{C}$ or even above (Maestri et al., 2001), especially if stomata are closed, as occurs on sunny days in unshaded plantations (Butler, 1977). Only under these extreme conditions of high irradiance would the negative effects of high temperatures in fact promote leaf chlorosis and burning (Cannell, 1985; Wrigley, 1988) due to chl photobleaching and extensive damage to the photosynthetic machinery. This would include strong (not easily reversible) impacts on the photochemical primary processes of PS II and the electron transport in thylakoids, as well as in the enzymes involved in the carboxylation and regeneration of RuBP pathway in the stroma (Nunes et al., 1993; Fahl et al., 1994; Ramalho et al., 1997, 1999, 2000).

The setting of adequate temperature limits for coffee is decisive for the distribution and economic exploitation 
of the crop. Also, taking into account the global warming phenomena, temperature may rise between 1 and $5.8^{\circ} \mathrm{C}$ in the tropical area up to the end of the XXI century, as reported by the Intergovernmental Panel on Climate Change. Considering the actual genetic and physiological characteristics of the cultivated Brazilian cultivars of arabica coffee, severe reductions of adequate areas for growing the crop are to be expected. These reductions might reach values as high as $95 \%$ in Goiás, Minas Gerais and São Paulo, and $75 \%$ in Paraná (Assad et al., 2004). That underlines the need to select/produce plants tolerant to higher temperatures. In any case, if such previsions were correct, cultivation of robusta would be favoured over that of arabica coffee, taking into account that the former can endure relatively higher temperatures than arabica, maintaining high $A$ values at temperatures up to $34-35^{\circ} \mathrm{C}$, provided that $g_{\mathrm{s}}$ is not limiting (Carelli et al., 1999; DaMatta et al., 2003). Alternatively, the use of shelter trees should become increasingly important, as they can effectively attenuate the impact of unfavourable temperatures.

\section{SHADING IN HARSH ENVIRONMENTS}

The implementation of improved coffee production systems must emphasize sustainability requirements, by promoting consistent yields while preserving a sound ecological environment (Rena et al., 1994). In this context, cultural practices such as shading, which conserve natural resources, have received renewed interest in the last years. Some reviews have examined shade management in coffee plantations (Beer, 1987; Beer et al., 1998), as well as the physiology and production of the coffee tree under shade conditions (DaMatta and Rena, 2002; DaMatta, 2004a,c).

Although native to shady environments, modern coffee cultivars have a wide plasticity in response to varying irradiance. Such cultivars grow well without shade and even may show higher productions than those of shaded trees, particularly in zones with adequate climate and soils (DaMatta, 2004a). However, there is an increasing trend in expanding coffee cultivation to marginal lands where water shortages and unfavourable temperatures may significantly constrain crop production. For example, search for good quality beverage has spread coffee cultivation towards the highlands of south-eastern Brazil where temperature may occasionally approaches $0^{\circ} \mathrm{C}$. In addition, coffee plantations have been also expanded towards warmer regions with prolonged, unpredictable droughts. In these harsh environments, the use of shelter trees is highly advisable in order to allow economic yields (DaMatta and Rena, 2002; DaMatta, 2004a).

The main effects of shade trees on crop physiology are associated with decreased wind speeds and temperature fluctuations (by as much as $4-5^{\circ} \mathrm{C}$ ), increased air relative humidity, and changes in aerodynamic roughness of the cropped area. Taken together, these alterations would decrease leaf-to-air $D$ and would increase $\Omega$, which in turn would allow longer stomatal opening (thus favouring $\mathrm{CO}_{2}$ uptake), without a proportional increase in $E$. Hence, water loss due to excessive $E T_{\mathrm{c}}$ is expected to be declined, an effect further facilitated by increased ground cover and decreased abundance of weeds. Indeed, adequate shade management may improve both the water status of the soil and the coffee plant after prolonged droughts. In addition, shade trees lead to a lower radiation input at the canopy level, so reducing the extent of photooxidative damage, a phenomenon frequently observed in coffee grown at full exposure in marginal zones. In these zones, therefore, provided that the agrosystem is correctly managed (proper choice of shade tree species, judicious evaluation of planting density, soil type, water and thermal regimens), water-use efficiency is expected to rise, turning the use of shade trees a highly recommended option. This should be translated into obvious advantages to the production of coffee plantations in dry environments. It should be emphasized that the drier and hotter the site is, the greater the benefit of shading, especially when associated with both irrigation and short-size cultivars with compact crowns. The use of cultivars with open crowns, even if irrigation is supplemented, often results in unsuccessful cropping. Taken together, these considerations emphasize the importance of maintaining a low leaf-to-air $D$ for allowing good coffee production (DaMatta, 2004a, and references therein).

Shading has been adopted to avoid large reductions in night temperatures at high elevations, as in Kenya (Carr, 2001), or at lower latitudes, as in Paraná State, southern Brazil (Caramori et al., 2003; Leal et al., 2003), in order to reduce chilling, and eventually frost, damage. The efficiency of shading, as a means to protect the coffee plant against radiative frosts, increases greatly as the plant is closer to the shelter tree (Caramori et al., 1995). For young coffee plantations, dense, temporary shading, as that obtained with the use of shelter shrubs such as pigeon pea (Cajanus cajan) is very effective against frosts. Recent work also reported promising results with the use of other methods, like cepilho and enterrio that confer a remarkable protection, since temperatures registered for small plants (5-6 pair of leaves) 
in the field were as much as $10^{\circ} \mathrm{C}$ higher than in the plants without protection (Caramori et al., 2003).

\section{CONCLUDING REMARKS}

In the last 15 years, relatively considerable amount of basic research on environmental coffee physiology focusing on water relations and drought tolerance mechanisms has been undertaken, but much less research effort has been devoted to identifying responses and mechanisms of tolerance to unfavourable temperatures. In any case, in coffee, as occurs with most tropical crop species, the gaps of knowledge on assimilate partitioning, hormonal relations, carbon and nitrogen metabolism, defence mechanisms against oxidative stress, etc., under such stressful conditions are still significant. Moreover, much research on coffee physiology has been conducted using potted seedlings under (semi)controlled conditions, and the results cannot always be extrapolated to the field. Despite the data on early physiological or biochemical changes obtained under such conditions being resolved to a greater degree of precision, a single and direct link between a particular trait and yield maintenance under drought or unfavourable temperature conditions has never been proven. Since yield improvements under the highly changing tropical environments are an imperious requirement, identification of traits associated with yield variation under field conditions remains to be achieved.

The use of molecular tools for studying responses of coffee to both drought and temperature has not been implemented in most studies, but is currently underway in some laboratories. New opportunities within the frontiers of molecular physiology should be opened since Brazilian research groups have just finished the first mapping of the arabica coffee genome, resulting in the sequencing of 200,000 expressed sequenced tags, forming a very useful database for cutting edge research. Such information can be expected to accelerate studies on coffee physiology and breeding, facilitating the production of cultivars with superior performance under adverse environmental conditions, such as drought and cold. Nevertheless, that could be complemented with adequate crop management, using, e.g., shade (agroforestry) systems as a promising alternative for sustainability in coffee exploitation. This seems to be a practical and useful means of buffering climatic fluctuations, thus rendering coffee cultivation less dependent on external inputs, such as supplemental fertilization and irrigation (DaMatta, 2004a). Fundamental research using new molecular tools and focusing on this subject is just beginning, and the impact of shading on rain-fed and irrigated coffee cropping systems, particularly in marginal lands, is a challenge to be handled within the near future.

Acknowledgements: F.M. DaMatta acknowledges the National Council for Scientific and Technological Development (CNPq, Brazil), the Brazilian Consortium for Coffee Research and Development, and the Foundation for Research Assistance of the Minas Gerais State for the fellowships held by him during the preparation of this manuscript. Results from J.D.C. Ramalho referred in the text were mainly obtained through the projects POCTI/AGG/43101/2001 and PRAXIS XXI/BD/21570/99 co-financed by the Foundation for Science and Technology, Portugal, and the European fund FEDER.

\section{REFERENCES}

Adams III WW, Barker DH (1998) Seasonal changes in xanthophyll cycle-dependent energy dissipation in Yucca glauca Nuttall. Plant Cell Environ. 21:501-511.

Adams III WW, Demmig-Adams B (1995) The xanthophyll cycle and sustained thermal energy dissipation in Vinca minor and Euonymus kiautschovicus in winter. Plant Cell Environ. 18:117-127.

Adams III WW, Demmig-Adams B, Rosenstiel TN, Brightwell AK, Ebbert V (2002) Photosynthesis and photoprotection in overwintering plants. Plant Biol. 4:545-557.

Alègre C (1959) Climates et caféiers d'Arabie. Agron. Trop. 14:23-58.

Allen DJ, Ort DR (2001) Impacts of chilling temperatures on photosynthesis in warm-climate plants. Trends Plant Sci. 6:36-42.

Almeida A-AF, Maestri M (1996) Characteristics of slow chlorophyll fluorescence emission in four Coffea arabi$c a$ genotypes submitted to water stress. Photosynthetica 32:161-169.

Almeida A-AF, Maestri M (1997) Photosynthetic oxygen evolution by four Coffea arabica genotypes subjected to a dehydration/rehydration cycle. J. Hort. Sci. 72:593-599.

Alonso A, Queiroz CS, Magalhães AC (1997) Chilling stress leads to increased cell membrane rigidity in roots of coffee (Coffea arabica L.) seedlings. Biochim. Biophys. Acta 1323:75-84.

Alscher RG, Donahue JL, Cramer C (1997) Reactive oxygen species and antioxidants: Relationships in green cells. Physiol. Plant. 100:224-233.

Androcioli Filho AF, Siqueira R, Caramori PH, Pavan MA, Sera T, Soderholm PK (1986) Frost injury and performance of coffee at $23^{\circ} \mathrm{S}$ in Brazil. Exp. Agric. 22:71-74.

Asada K (1994) Mechanisms for scavenging reactive molecules generated in chloroplasts under light stress. In: Baker NR, Bowyer JR (eds), Photoinhibition of Photosynthesis - From Molecular Mechanisms to the Field, pp.129-142. Bios Scientific Publishers, Oxford. 
Asada K, Takahashi M (1987) Production and scavenging of active oxygen in photosynthesis. In: Kyle DJ, Osmond CB, Arntzen CJ (eds), Photoinhibition, pp.227-287. Topics in Photosynthesis, Vol 9, Elsevier, Amesterdam.

Assad ED, Pinto HS, Zullo Jr. J, Ávila AMH (2004) Impacto das mudanças climáticas no zoneamento agroclimático do café no Brasil. Pesq. Agropec. Bras. 39:1057-1064.

Barros RS, Mota JW, DaMatta FM, Maestri M (1997) Decline of vegetative growth in Coffea arabica L. in relation to leaf temperature, water potential and stomatal conductance. Field Crops Res. 54:65-72.

Barros RS Maestri M, Rena AB 1995. Coffee crop ecology. Trop. Ecol. 36:1-19.

Barros RS, Maestri M, Rena AB (1999) Physiology of growth and production of the coffee tree - a review. J. Coffee Res. 27:1-54

Bauer H, Comploj A, Bodner M (1990) Susceptibility to chilling of some Central-African cultivars of Coffea arabica. Field Crops Res. 24:119-129.

Bauer H, Wierer R, Hatheway WH, Larcher W (1985) Photosynthesis of Coffea arabica after chilling. Physiol. Plant. 64:449-454.

Beer J (1987) Advantages, disadvantages and desirable characteristics of shade for coffee, cacao and tea. Agrofor. Syst. 5:3-13.

Beer J, Muschler R, Kass D, Somarriba E (1998) Shade management in coffee and cacao plantations. Agrofor. Syst. 38:139-164.

Bierhuizen JF, Nunes MA, Ploegman C (1969) Studies on productivity of coffee. II. Effect of soil moisture on photosynthesis and transpiration. Acta Bot. Neerl. 18:367-374.

Blake TJ, Tshaplinski TJ (1992) Water relations. In: Mitchell CP, Ford-Robertson JB, Hinckley T, Sennerby-Forsse L (eds), Ecophysiology of Short Rotation Forest Crops, pp.66-94. Elsevier, London.

Bodner M, Larcher W (1987) Chilling susceptibility of different organs and tissues of Saintpaulia ionantha and Coffea arabica. Angew. Bot. 61:225-242.

Boyer J (1965) Comportement hydrique des deux grands groupes de Coffea canephora de Côte d'Ivoire. Café Cacao Thé 9:263-282.

Bray EA, Bailey-Serres J, Weretilnyk (2000) Responses to abiotic stresses. In: Buchanan E, Gruissem W, Jones R (eds), Biochemical and Molecular Biology of Plants, pp.1158-1249. American Society of Plant Physiologists, Rockville.

Browning G, Fisher NM (1975) Shoot growth in Coffea arabica L., II Growth flushing stimulated by irrigation. J. Hort. Sci. 50:207-218.

Brunini O, Angelocci LR (1998) Resistência ao fluxo de água no sistema solo-planta e recuperação do potencial da água na folha após estresse hídrico em mudas de cafeeiro. Rev. Bras. Fisiol. Veg. 10:45-50.

Butler DR (1977) Coffee leaf temperatures in a tropical environment. Acta Bot. Neerl. 26:129-140.

Byrd GT, Ort DR, Ogren WL (1995) The effects of chilling in the light on the ribulose-1,5-bisphosphate carboxylase/ oxygenase activation in tomato (Lycopersicon esculentum Mill.). Plant Physiol. 107:585-591.

Camargo AP (1985) O clima e a cafeicultura no Brasil. Inf. Agropec. 11:13-26.

Campos PS, Quartin V, Ramalho JC, Nunes MA (2003) Electrolyte leakage and lipid degradation account for cold sensitivity in leaves of Coffea sp. plants. J. Plant Physiol. 160: 283-292.

Cannell MG (1976) Crop physiological aspects of coffee bean yield - a review. Kenya Coffee 41:245-253.

Cannell MG (1985) Physiology of the coffee crop. In: Clifford MN, Willson KC (eds), Coffee - Botany, Biochemistry and Production of Beans and Beverage, pp.108-134. Crom Helm, London.

Caramori LPC, Caramori PH, Manetti Filho J (2002) Effect of leaf water potential on cold tolerance of Coffea arabica L. Braz. Arch. Biol. Technol. 45:439-443.

Caramori PH, Androcioli Filho A, Bagio A (1995) Arborização do cafezal com Grevillea robusta no norte do estado do Paraná. Arq. Biol. Tecnol. 38:1031-1037.

Caramori PH, Grodzki L, Morais H, Juliato H (2003) Efeito da geada em mudas de café sob diferentes métodos de proteção. In: Book of Abstracts of the III Simpósio de Pesquisas dos Cafés do Brasil, Embrapa Café, Brasília, pp.66.

Caramori PH, Ometto JC, Nova NA, Costa JD (1986) Efeitos do vento sobre mudas de cafeeiro Mundo Novo e Catuaí Vermelho. Pesq. Agropec. Bras. 21:1113-1118.

Carelli MLC, Fahl JI (1991) Distribuição da assimilação de nitrato e de matéria seca em plantas jovens de café cultivadas em diferentes níveis de nitrogênio. Bragantia 50:29-37

Carelli MLC, Fahl JI, Trivelin PCO, Queiroz-Voltan RB (1999) Carbon isotope discrimination and gas exchange in Coffea species grown under different irradiance regimes. Braz. J. Plant Physiol. 11:63-68.

Carr MKV (2001) The water relations and irrigation requirements of coffee. Exp. Agric. 37:1-36.

Carvajal JF (1984) Cafeto - Cultivo y Fertilización. Instituto Internacional de la Potassa, Berna.

Chaves JCD, Manetti Filho J (1990) Danos de geadas em cafeeiros submetidos a adubação potássica e calagem. In: Resumes of the XVI Congresso Brasileiro de Pesquisas Cafeeiras. IBC, Rio de Janeiro, pp. 86.

Chaves MM (1991) Effects of water deficits on carbon assimilation. J. Exp. Bot. 42:1-16.

Coste R (1992) Coffee - The Plant and the Product. MacMillan Press, London.

DaMatta FM (2003) Drought as a multidimensional stress affecting photosynthesis in tropical tree crops. In: Hemantaranjan A (ed), Advances in Plant Physiology, Vol. 5, pp.227-265. Scientific Publishers, Jodhpur.

DaMatta FM (2004a) Ecophysiological constraints on the production of shaded and unshaded coffee: a review. Field Crops Res. 86:99-114.

DaMatta FM (2004b) Exploring drought tolerance in coffee: a physiological approach with some insights for plant breeding. Braz. J. Plant Physiol. 16:1-6. 
DaMatta FM (2004c) Fisiologia do cafeeiro em sistemas arborizados. In: Matsumoto SN (ed), Arborização de Cafezais no Brasil, pp. 85-118. Edições UESB, Vitória da Conquista.

DaMatta FM, Amaral JA, Rena AB (1999) Growth periodicity in trees of Coffea arabica L. in relation to nitrogen supply and nitrate reductase activity. Field Crops Res. 60: 223-229.

DaMatta FM, Chaves ARM, Pinheiro HA, Ducatti C, Loureiro ME (2003) Drought tolerance of two field-grown clones of Coffea canephora. Plant Sci. 164:111-117.

DaMatta FM, Loos RA, Rodrigues R, Barros RS (2001) Actual and potential photosynthetic rates of tropical crop species. Braz. J. Plant Physiol. 13:24-32.

DaMatta FM, Loos RA, Silva EA, Ducatti C, Loureiro ME (2002a) Effects of soil water deficit and nitrogen nutrition on water relations and photosynthesis of pot-grown Coffea canephora Pierre. Trees - Struct. Funct. 16:555-558.

DaMatta FM, Loos RA, Silva EA, Loureiro ME (2002b) Limitations to photosynthesis in Coffea canephora as a result of nitrogen and water availability. J. Plant Physiol. 159: 975-981.

DaMatta FM, Maestri M, Barros RS (1997a) Photosynthetic performance of two coffee species under drought. Photosynthetica 34:257-264.

DaMatta FM, Maestri M, Mosquim PR, Barros RS (1997b) Photosynthesis in coffee (Coffea arabica and C. canepho$\mathrm{ra}$ ) as affected by winter and summer conditions. Plant Sci. 128:43-50.

DaMatta F M, Maestri M, Barros RS, Regazzi A J (1993) Water relations of coffee leaves (Coffea arabica and C. canepho$\mathrm{ra}$ ) in response to drought. J. Hort. Sci. 68:741-746.

DaMatta FM, Rena AB (2001) Tolerância do café à seca. In: Zambolin L (ed), Tecnologias de Produção de Café com Qualidade, pp.65-100. Universidade Federal de Viçosa, Viçosa.

DaMatta FM, Rena AB (2002a) Ecofisiologia de cafezais sombreados e a pleno Sol. In: Zambolim L (ed), O Estado da Arte de Tecnologias na Produção de Café, pp.93-135. Universidade Federal de Viçosa, Viçosa.

DaMatta FM, Rena AB (2002b) Relações hídricas no cafeeiro. In: Encarnação RO, Afonso Jr PC, Rufino JLS (eds), I Simpósio de Pesquisa dos Cafés do Brasil: Palestras, pp.944. Embrapa Café, Brasília.

DaMatta FM, Silveira JSM, Ducatti C, Loureiro ME (2000) Eficiência do uso da água e tolerância à seca em Coffea canephora. In: Expanded Abstracts of the I Simpósio de Pesquisa dos Cafés do Brasil. Embrapa Café, Brasília, pp. 907-910.

De Las Rivas J, Telfer A, Barber J (1993) Two coupled betacarotene molecules protect $\mathrm{P}_{680}$ from photodamage in isolated photosystem two reaction centres. Biochim. Biophys. Acta 1142:155-164.

Fahl JI, Carelli MLC, Gallo PB, Costa WM, Novo MCSS (1998) Efeito da enxertia de Coffea arabica sobre $C$. canephora e $C$. congensis no crescimento, nutrição mineral e na produção das plantas. Bragantia 57:297-312.
Fahl JI, Carelli MLC, Menezes HC, Gallo PB, Trivelin PCO (2001) Gas exchange, growth, yield and beverage quality of Coffea arabica cultivars grafted on to C. canephora and C. congensis. Exp. Agric. 37:241-252.

Fanjul L, Arreola-R R, Mendez-C MP (1985) Stomatal responses to environmental variables in shade and sun grown coffee plants in Mexico. Exp. Agric. 21:249-258.

Farquhar GD, Ehleringer JR, Hubick KT (1989) Carbon isotope discrimination and photosynthesis. Annu. Rev. Plant Physiol. Plant Mol. Biol. 40:503-537.

Fazuoli LC, Camargo AP, Piccin C (1995) O café Icatu desenvolvido no IAC para resistência ao agente da ferrugem vem mostrando também em plantas adultas tolerância à geada. In: Proceedings of the $21^{\circ}$ Congresso Brasileiro de Pesquisas Cafeeiras, IBC, Rio de Janeiro, pp.138-140.

Feio M (1991) Clima e Agricultura. Ministério da Agricultura, Pescas e Alimentação, Lisboa.

Foyer CH (2002) The contribution of photosynthetic oxygen metabolism to oxidative stress in plants. In: Inzé D, Van Montagu M (eds), Oxidative Stress in Plants, pp. 33-68. Taylor \& Francis, London.

Foyer CH, Lelandais M, Kunert KJ (1994) Photooxidative stress in plants. Physiol. Plant. 92:696-717.

Franco CM (1958) Influence of temperature on growth of coffee plant. IBEC Research Institute, New York. Bulletin No. 16.

Gascó A, Nardini A, Salleo S (2004) Resistance to water flow through leaves of Coffea arabica is dominated by extra-vascular tissues. Funct. Plant Biol. 31:1161-1168.

Geiger DR, Servaites JC, Shieh W-J (1992) Balance in the source-sink system: a factor in crop productivity. In: Baker NR, Thomas H (eds), Crop Photosynthesis: Spatial and Temporal Determinants, pp.155-176. Topics in Photosynthesis, Vol. 12. Elsevier, Amesterdam.

Gigon A, Matos AR, Laffray D, Zuily-Fodil Y, Pham-Thi AT (2004) Effect of drought stress on lipid metabolism in the leaves of Arabidopsis thaliana (Ecotype Columbia). Ann. Bot. 94:345-351.

Golberg AD, Bierny O, Renard C (1984) Évolution comparée des paramètres hydriques chez Coffea canephora Pierre et l'hybride Coffea arabusta Capot et Aké Assi. Café Cacao Thé 28:257-266.

Gray RG, Chauvin L-P, Sarhan F, Huner NPA (1997) Cold acclimation and freezing tolerance. A complex interaction of light and temperature. Plant Physiol. 114:467-474.

Guimarães RJ, Mendes AN, Souza CA (2002) Solo e clima para o cafeeiro. In Guimarães RJ, Mendes AN, Souza CA (eds), Cafeicultura, pp.124-138. Universidade Federal de Lavras, Lavras.

Gutiérrez MV, Meinzer FC (1994a) Estimating water use and irrigation requirements of coffee in Hawaii. J. Am. Soc. Hort. Sci. 119:652-657.

Gutiérrez MV, Meinzer FC (1994b) Energy balance and latent heat flux partitioning in coffee hedgerows at different stages of canopy development. Agric. For. Meteorol. 68:173-186. 
Gutiérrez MV, Meinzer FC, Grantz DA (1994) Regulation of transpiration in coffee hedgerows: Covariation of environmental variables and apparent responses of stomata to wind and humidity. Plant Cell Environ. 17:1305-1313.

Haarer AE (1958) Modern Coffee Production. Leonard Hill, London.

Haldimann P (1998) Low growth temperature-induced changes to pigment composition and photosynthesis in Zea mays genotypes differing in chilling sensitivity. Plant Cell Environ. 21:200-208.

Hällgreen J-E, Öquist G. (1990) Adaptations to low temperatures. In: Alscher RT, Cumming JR (eds), Stress Responses in Plants: Adaptation and Acclimation Mechanisms, pp.265-293. Plant Biology Series, Vol. 12., Wiley-Liss, New York.

Hare PD, Cress WA, van Staden J (1998) Dissecting the roles of osmolyte accumulation during stress. Plant Cell Environ. 21:535-553.

Harwood JL (1988) Fatty acid metabolism. Annu. Rev. Plant Physiol. Plant Mol. Biol. 29:101-138.

Harwood JL (1997) Plant lipid metabolism. In: Dey PM, Harborne JB (eds), Plant Biochemistry, pp.237-271. Academic Press, San Diego.

Havaux M, Kloppstech K (2001) The protective functions of carotenoid and flavonoid pigments against excess visible radiation at chilling temperature investigated in Arabidopsis $n p q$ and $t t$ mutants. Planta 213:953-966.

Havaux M, Niyogi KK (1999) The violaxanthin cycle protects plants from photooxidative damage by more than one mechanism. Proc. Natl. Acad. Sci. USA 96:8762-8767.

Heath OVS, Orchard B (1957) Midday closure of stomata. Temperature effects on the minimum intercellular space carbon dioxide concentration " $\Gamma$ ". Nature 180:180-182.

Hernández MP, Cock JH, El-Sharkawy A (1989) The responses of leaf gas exchange and stomatal conductance to air humidity in shade-grown coffee, tea and cacao plants as compared with sunflower. Rev. Bras. Fisiol. Veg. 1:155-161.

Horton P, Ruban AV, Walters RG (1996) Regulation of light harvesting in green plants. Annu. Rev. Plant Physiol. Plant Mol. Biol. 47:655-684.

Horváth G, Melis A, Hideg É, Droppa M, Vigh L (1987) Role of lipids in the organization and function of photosystem II studied by homogeneous catalytic hydrogenation of thylakoid membranes in situ. Biochim. Biophys. Acta 891:68-74.

Huner N, Williams JP, Maissan EE, Myscich EG, Krol M, Laroche A, Singh J (1989) Low temperature-induced decrease is trans- $\Delta^{3}$-hexadecenoic acid content is correlated with freezing tolerance in cereals. Plant Physiol. 89:144-150.

Hurry V, Huner N, Selstam E, Gardeström P, Öquist G (1998) Photosynthesis at low growth temperatures. In: Raghavendra AS (ed), Photosynthesis. A Comprehensive Treatise, pp.238-249. Cambridge: University Press, Cambridge.

IARC (1991) Coffee, Tea, Mate, Methylxanthines and Methylglyoxal. Vol 51, Monographs on the Evaluation of Carcinogenic Risks to Humans. International Agency for Research on Cancer - World Health Organization, Lyon.
Iba I (2002) Acclimation response to temperature stress in higher plants: approaches of gene engeneering for temperature tolerance. Annu. Rev. Plant Physiol. Plant Mol. Biol. 53:225-245.

IBC (1985) Cultura do Café no Brasil - Manual de Recomendações. Instituto Brasileiro do Café - G.E.R.C.A., Rio de Janeiro.

Jarvis PG, McNaughton KG (1986) Stomatal control of transpiration: scaling up from leaf to region. Adv. Ecol. Res. 15:1-49.

Jones HG (1998) Stomatal control of photosynthesis and transpiration. J. Exp. Bot. 49:387-398.

Josis P, Ndayishimiye V, Rénard C (1983) Étude des relations hydriques chez Coffea arabica L. II. Évaluation de la resistance à la secheresse de divers cultivars à Ghisa (Burundi). Café Cacao Thé 27:275-282.

Kanechi M, Uchida NU, Yasuda T, Yamaguchi T (1988) Relationships between leaf water potential and photosynthesis of Coffea arabica L. grown under various environmental conditions as affected by withholding irrigation and reirrigation. Jap. J. Trop. Agric. 32:16-21.

Kanechi M, Uchida NU, Yasuda T, Yamaguchi T (1991) Photosynthetic responses of Coffea arabica L. to chronic dehydration during leaf development and after leaf maturation in unshaded and shaded conditions. Jap. J. Trop. Agric. 35:84-91.

Kanechi M, Uchida NU, Yasuda T, Yamaguchi T (1995a) Water stress effects on leaf transpiration and photosynthesis of Coffea arabica L. under different irradiance conditions. In: Proceedings of the $16^{\text {th }}$ International Scientific Colloquium on Coffee, Kyoto. 1995. Association Scientifique Internationale du Café, Paris, pp.520-527.

Kanechi M, Uchida NU, Yasuda T, Yamaguchi T (1995b) Water stress effects on leaf photosynthesis and diffusive conductances of three Coffea species (C. arabica, C. canephora, $C$. liberica) In: Proceedings of the $16^{\text {th }}$ International Scientific Colloquium on Coffee, Kyoto. 1995. Association Scientifique Internationale du Café, Paris, pp.804-810.

Kanechi M, Uchida NU, Yasuda T, Yamaguchi T (1996) Nonstomatal inhibition associated with inactivation of rubisco in dehydrated coffee leaves under unshaded and shaded conditions. Plant Cell Physiol. 37:455-460.

Karpinski S, Wingsle G, Karpinska B, Hällgren J-E (2002) Low-temperature stress and antioxidant defense mechanisms in higher plants. In: Inzé D, Van Montagu M (eds), Oxidative Stress in Plants, pp.69-103. Taylor \& Francis, London.

Kasprzewska A (2003) Plant chitinases - regulation and function. Cel. Mol. Biol. Lett. 8:809-824.

Kornyeyev D, Logan BA, Payton P, Allen RD, Holaday AS (2001) Enhanced photochemical light utilization and decreased chilling-induced photoinhibition of photosystem II in cotton overexpressing genes encoding chloroplast-targeted antioxidant enzymes. Physiol. Plant. 113:323-331.

Kratsch HA, Wise RR (2000) The ultrastructure of chilling stress. Plant Cell Environ. 23:337-350. 
Krause GH (1994) Photoinhibition induced by low temperatures. In: Baker NR, Bowyer JR (eds), Photoinhibition of Photosynthesis - From Molecular Mechanisms to the Field, pp.331-348. Bios Scientific Publishers, Oxford.

Krishna P (2004) Plant responses to heat stress. In: Hirt H, Shinozaki K (eds), Plant Responses to Abiotic Stress, pp.72101. Topics in Current Genetics, Springer-Verlag, Berlin.

Krivosheeva A, Tao D-L, Ottander C, Öquist G, Wingsle G (1996) Cold acclimation and photoinhibition of photosynthesis in Scots pine. Planta 200:296-305.

Kumar D, Tieszen LL (1976) Some aspects of photosynthesis and related processes in Coffea arabica L. Kenya Coffee 41:309-315.

Kumar D, Tieszen LL (1980a) Photosynthesis in Coffea arabica. I. Effects of light and temperature. Exp. Agric. 16: 13-19.

Kumar D, Tieszen LL (1980b) Photosynthesis in Coffea arabica. I. Effects of water stress. Exp. Agric. 16:21-27.

Larcher W (1981) Effects of low temperature stress and frost injury on plant productivity. In: Johnson CB (ed), Physiological Processes Limiting Plant Productivity, pp.253-269. Butterworths, London.

Larcher W (1995) Physiological Plant Ecology. $3^{\text {rd }}$ Ed. Springer-Verlag, Berlin.

Lawlor DW (2001) Photosynthesis. $3^{\text {rd }}$ Ed. Bios Scientific Publishers, Oxford.

Lawlor DW (2002) Limitation to photosynthesis in waterstressed leaves: stomata vs metabolism and the role of ATP. Ann. Bot. 89:275-294.

Lawlor DW, Cornic G (2002) Photosynthetic carbon assimilation and associated metabolism in relation to water deficits in higher plants. Plant Cell Environ. 25:275-294.

Leal AC, Caramori PH, Soares RV, Batista AC (2003) Avaliação dos danos causados por geada severíssima em cafeeiros sob a área de influência das copas de quatro espécies florestais em Londrina, PR. In: Book of Abstracts of the III Simpósio de Pesquisas dos Cafés do Brasil, Embrapa Café, Brasília, pp. 59.

Leegood RC (1995) Effects of temperature on photosynthesis and photorespiration. In: Smirnoff N (ed), Environment and Plant Metabolism - Flexibility and Acclimation, pp.4562. Bios Scientific Publishers, Oxford.

Lidon FC, Leitão E, Pais IP, Santiago C, Ribeiro A, Ramalho JC (2004) Antioxidative system as a determinant component of cold tolerance in Coffea sp. In: Book of Abstracts of the XIV Congresso Nacional de Bioquímica, PG.1. Vilamoura, pp. 88.

Lima AL, DaMatta FM, Pinheiro HA, Totola MR, Loureiro ME (2002) Photochemical responses and oxidative stress in two clones of Coffea canephora under water deficit conditions. Environ. Exp. Bot. 47:239-247.

Maestri M, Barros RS (1977) Coffee. In: Alvim PT, Kozlowski TT (eds), Ecophysiology of Tropical Crops, pp.249-278. Academic Press, London.

Maestri M, Barros RS, Rena AB (2001) Coffee. In: Last FT (ed), Tree Crop Ecosystems, pp.339-360. Elsevier Publishers, Amsterdam.
Maestri M, DaMatta FM, Regazzi AJ, Barros RS (1995) Accumulation of proline and quaternary ammonium compounds in mature leaves of water stressed coffee plants (Coffea arabica and C. canephora). J. Hort. Sci. 70:229-233.

Manetti Filho J, Caramori PH (1986) Desenvolvimento de uma câmara para simulação de temperaturas baixas. Pesq. Agropec. Bras. 21:1005-1008.

Mano J (2002) Early events in environmental stresses in plants - Induction mechanisms of oxidative stress. In: Inzé D, Van Montagu M (eds), Oxidative Stress in Plants, pp.217-245. Taylor \& Francis, London.

Matiello JB (1998) Café Conillon: Como Plantar, Tratar, Colher, Preparar e Vender. MM Produções Gráficas, Rio de Janeiro.

Matiello JB, Santinato R, Garcia AWR, Almeida SR, Fernandes DR (2002) Cultura de Café no Brasil: Novo Manual de Recomendações. MAPA/PROCAFÉ, Rio de Janeiro.

Mazzafera P, Teixeira JPF (1989) Prolina em cafeeiros submetidos a déficit hídrico. Turrialba 39:305-313.

Meguro NE, Magalhães AC (1983) Water stress affecting nitrate reduction and leaf diffusive resistance in Coffea arabica L. cultivars. J. Hort. Sci. 58:147-152.

Meinzer FC, Goldstein G, Grantz DA (1990a) Carbon isotope discrimination in coffee genotypes grown under limited water supply. Plant Physiol. 92:130-135.

Meinzer FC, Grantz DA, Goldstein G, Saliendra NZ (1990b) Leaf water relations and maintenance of gas exchange in coffee cultivars grown in drying soil. Plant Physiol. 94: 1781-1787.

Meinzer FC, Ingamells JL, Crisosto C (1991) Carbon isotope discrimination correlates with bean yield of diverse coffee seedling populations. HortScience 26:1413-1414.

Meinzer FC, Saliendra NZ, Crisosto CH (1992) Carbon isotope discrimination and gas exchange in Coffea arabica during adjustment in different soil moisture regimes. Aust. J. Plant Physiol. 19:171-184.

Menezes GRO (2005) Estresse oxidativo mediado por paraquat e clonagem do gene da dismutase do superóxido $(\mathrm{Cu} / \mathrm{Zn}$ SOD) em Coffea canephora. Viçosa, Universidade Federal de Viçosa, Master's Thesis.

Moon BY, Higashi S, Gombos Z, Murata N (1995) Unsaturation of the membrane lipids of chloroplasts stabilizes the photosynthetic machinery against low-temperature photoinhibition in transgenic tobacco plants. Proc. Natl. Acad. Sci. U.S.A. 92:6219-6223.

Moraes FR (1963) Meio ambiente e práticas culturais. In: Cultura e Adubação do Cafeeiro, pp. 77-126. Instituto Brasileiro da Potassa, São Paulo.

Morcuende R, Pérez P, Martínez-Carrasco R, Molino IM, Puente LS (1996) Long- and short-term responses of leaf carbohydrate levels and photosynthesis to decreased sink demand in soybean. Plant Cell Environ. 19:976-982.

Müller P, Li X-P, Niyogi KK (2001) Non-photochemical quenching. A response to excess light energy. Plant Physiol. 155:1558-1566.

Munné-Bosch S, Alegre L (2002) The function of tocopherols and tocotrienols in plants. Crit. Rev. Plant Sci. 21:31-57. 
Munns R (1988) Why measure osmotic adjustment? Aust. J. Plant Physiol. 5:207-218.

Nishida I, Murata N (1996) Chilling sensitivity in plants and cyanobacteria: The crucial contribution of membrane lipids. Annu. Rev. Plant Physiol. Plant Mol. Biol. 47:541-568.

Niyogi KK (1999) Photoprotection revisited: genetic and molecular approaches. Annu. Rev. Plant Physiol. Plant Mol. Biol. 50:333-359.

Niyogi KK, Björkman O, Grossman A (1997) The roles of specific xanthophylls in photoprotection. Proc. Natl. Acad. Sci. USA 94:14161-14167.

Nunes MA (1976) Water relations in coffee: significance of plant water deficits to growth and yield: a review. J. Coffee Res. 6:4-21.

Nunes MA (1988) Environmental effects on the stomatal and mesophyll regulation of photosynthesis in coffee leaves. Photosynthetica 22:547-553.

Nunes MA, Bierhuizen JF, Ploegman C (1968) Studies on the productivity of coffee. I. Effects of light, temperature and $\mathrm{CO}_{2}$ concentration on photosynthesis of Coffea arabica. Acta Bot. Neerl.17: 93-102.

Nunes MA, Brumby D, Davies DD (1973) Estudo comparativo do metabolismo fotossintético em folhas de cafeeiro, beterraba e cana-de-açúcar. Garcia de Orta, Série Estudos Agronómicos 1:1-14.

Nunes MA, Correia MM (1983) Regulação estomática da água disponível no solo em C. arabica L. (cvs. Caturra, Catuaí e Harrar). Garcia de Orta, Série Estudos Agronómicos 10:83-90.

Nunes MA, Ramalho JC, Dias MA (1993) Effect of nitrogen supply on the photosynthetic performance of leaves from coffee plants exposed to bright light. J. Exp. Bot. 44: 893-899.

Orozco-C FV, Jaramillo-R A (1978) Comportamiento de introducciones de Coffea sometidas a condiciones de déficit de humedad en el suelo. Cenicafé 29:61-93.

Perl-Treves R, Perl A (2002) Oxidative stress: An introduction. In: Inzé D, Van Montagu M (eds), Oxidative Stress in Plants, pp.1-32. Taylor \& Francis, London.

Petek MR, Alteia MZ, Sera T, Azevedo JA, Fadelli S, Colombo LA, Mata JS (2000) Avaliação do dano de geada de Julho de 2000 em progênies resistentes a ferrugem do ensaio EMF9601 em Londrina, Paraná. In: Proceedings of the $26^{\circ}$ Congresso Brasileiro de Pesquisas Cafeeiras, MAPA, Rio de Janeiro, pp.269-271.

Pinheiro HA (2004) Physiological and morphological adaptations as associated with drought tolerance in robusta coffee (Coffea canephora Pierre var. kouillou). Viçosa, Universidade Federal de Viçosa, PhD Thesis.

Pinheiro HA, DaMatta FM, Chaves ARM, Fontes EPB, Loureiro ME (2004) Drought tolerance in relation to protection against oxidative stress in clones of Coffea canephora subjected to long-term drought. Plant Sci. 167:1307-1314.

Pinheiro HA, DaMatta FM, Chaves ARM, Loureiro ME, Ducatti C (2005) Drought tolerance is associated with rooting depth and stomatal control of water use in clones of Coffea canephora. Ann. Bot. 96:101-108

Pogson BJ, Niyogi KK, Björkman O, Dellapenna D (1998) Altered xanthophyll compositions adversaly affected chlo- rophyll accumulation and nonphotochemical quenching in Arabidopsis mutants. Proc. Natl. Acad. Sci. USA 95:1332413329.

Praxedes SC, DaMatta FM, Loureiro ME, Ferrão MAG, Cordeiro AT (2005) Effects of long-term soil drought on photosynthesis and carbohydrate metabolism in mature robusta coffee (Coffea canephora Pierre var. kouillou) leaves. Environ. Exp. Bot., in press.

Quarrie SA, Stojanović J, Perić S (1999) Improving drought resistance in small-grained cereals: A case study, progress and prospects. Plant Growth Regul. 29:1-21.

Quartin VL, Ramalho JC, Campos PS, Fahl JI, Nunes MA (1998) Chilling effects on photosynthetic activity and membrane leakage of two species of Coffea. In: Garab G (ed), Photosynthesis: Mechanisms and Effects, Vol. IV, pp.25292532. Kluwer Academic Publishers, The Hague.

Quartin VL, Ramalho JC, Campos PS, Nunes MA (2000) Does dehydration play a role in the reduction of photosynthetic activity during chilling in Coffea sp.? In: Proceedings of the V Symposium Hispano-Português de Relaciones Hídricas en las Plantas, Alcalá de Henares, pp.260-261.

Quartin VL, Ramalho JC, Campos PS, Nunes MA (2004) A importância da investigação na cafeicultura: O problema do frio. In: Proceedings of the $1^{\circ}$ Colóquio sobre Agricultura, Sociedade e Desenvolvimento Rural em Angola. Instituto Superior de Agronomia Press, Lisboa, pp. 64-72.

Queiroz CGS, Alonso A, Mares-Guia M, Magalhães AC (1998) Chilling-induced changes in membrane fluidity and antioxidant enzyme activities in Coffea arabica L. roots. Biol. Plant. 41:403-413.

Ramalho JC, Campos PS, Quartin VL, Silva MJ, Nunes MA (1999) High irradiance impairments on photosynthetic electron transport, ribulose-1,5-bisphosphate carboxylase/ oxygenase and $\mathrm{N}$ assimilation as a function of $\mathrm{N}$ availability in Coffea arabica L. plants. J. Plant Physiol. 154: 319-326.

Ramalho JC, Campos PS, Teixeira M, Nunes MA (1998) Nitrogen dependent changes in antioxidant systems and in fatty acid composition of chloroplast membranes from Coffea arabica L. plants submitted to high irradiance. Plant Sci.135:115-124.

Ramalho JC, Pons TL, Groeneveld HW, Nunes MA (1997) Photosynthetic responses of Coffea arabica L. leaves to a short-term high light exposure in relation to $\mathrm{N}$ availability. Physiol. Plant. 101:229-239.

Ramalho JC, Pons TL, Groeneveld HW, Azinheira HG, Nunes MA (2000) Photosynthetic acclimation to high light conditions in mature leaves of Coffea arabica L.: role of xanthophylls, quenching mechanisms and nitrogen nutrition. Aust. J. Plant Physiol. 27:43-51.

Ramalho JC, Quartin V, Fahl JI, Carelli ML, Leitão AE, Nunes MA (2003) Cold acclimation ability of photosynthesis among species of the tropical Coffea genus. Plant Biol. 5:631-641.

Ramos LS, Carvalho A (1997) Shoot and root evaluations on seedlings from Coffea genotypes. Bragantia 56:59-68.

Ramos LS, Lima MMA (1980) Avaliação da superfície relativa do sistema radicular de cafeeiros. Bragantia 39:1-5. 
Rena AB, Barros RS, Maestri M, Söndahl MR (1994) Coffee. In: Schaffer B, Andersen PC (eds), Handbook of Environmental Physiology of Tropical Fruit Crops: Sub-Tropical and Tropical Crops, Vol. II, pp.101-122. CRC Press, Boca Raton.

Rena AB, DaMatta FM (2002) O sistema radicular do cafeeiro: estrutura e ecofisiologia. In: Zambolin L (ed) O Estado da Arte de Tecnologias na Produção de Café, pp.11-92. Universidade Federal de Viçosa, Viçosa.

Renard C, Karamaga P (1984) Étude des relations hydriques chez Coffea arabica L. III. Evolution de la conductance stomatique et des composantes du potentiel hydrique chez deux cultivars soumis à la sécheresse en conditions contrôlées. Café Cacao Thé 28:155-164.

Ronchi CP, Caten AT, Moraes GABK, Batista KD, Chaves ARM, DaMatta FM (2005) Efeitos de taxas de imposição e severidade do déficit hídrico sobre o metabolismo de carboidratos em folhas de Coffea canephora. In: Annals of the III Simpósio de Pesquisa dos Cafés do Brasil. Embrapa Café, Brasília (extended abstract on CD-ROM).

Routaboul J-M, Fischer S, Browse J (2000) Trienoic fatty acids are required to maintain chloroplast function at low temperature. Plant Physiol. 124:1697-1705.

Santos P, Machado E, Gouveia M, Fernandez D, Chen Z, Rodrigues Jr. CJ, Lidon FC, Ramalho JC, Ribeiro A (2004) Gene expression analysis of Coffea spp. exposed to biotic and abiotic stress. In: Book of Abstracts of the XIV Congresso Nacional de Bioquímica, PB.19, Vilamoura, pp. 46.

Segura-M A (1989) Efeito da pulverização com uréia, cloreto de potássio e sacarose sobre a transpiração, potencial hídrico e nitrogênio, potássio e açúcares nas folhas de mudas de Coffea arabica L. submetidas a défice de água. Universidade Federal de Viçosa, Viçosa, Master's Thesis.

Sentelhas PC, Fazuoli LC, Pezzopane JR (1995) Temperatura letal de diferentes espécies e derivados de híbrido interespecífico de café. In: Proceedings of the $21^{\circ}$ Congresso Brasileiro de Pesquisas Cafeeiras, IBC, Rio de Janeiro, pp.156-157.

Sera T, Guerreiro A (1998) Dano de geada e as características agronômicas das variedades de café (C. arabica L). In: Proceedings of the $24^{\circ}$ Congresso Brasileiro de Pesquisas Cafeeiras, PROCAFÉ, Rio de Janeiro, pp.282-284.

Siefermann-Harms D (1988) High-performance liquid chromatography of chloroplast pigments. One-step separation of carotene and xanthophyll isomers, chlorophylls and pheophytins. J. Chromatog. 448:411-416.

Silva EA, DaMatta FM, Ducatti C, Regazzi AJ, Barros RS (2004) Seasonal changes in vegetative growth and photosynthesis of Arabica coffee trees. Field Crops Res. 89: 349-357.

Smirnoff N (1995) Antioxidant systems and plant response to the environment. In: Smirnoff N (ed), Environment and Plant Metabolism - Flexibility and Acclimation, pp.217243. Bios Scientific Publishers, Oxford.

Smith AW (1989) Introduction. In: Clarke RJ, Macrae R (eds), Coffee, Vol. 1 - Chemistry, pp.1-41. Elsevier, London.
Sonoike K (1996) Photoinhibition of photosystem I: its physiological significance on the chilling sensitivity of plants. Plant Cell Physiol. 37:239-247.

Sylvain P (1955) Some observations on Coffea arabica L. in Ethiopia. Turrialba 5:37-53.

Tausend PC, Goldstein G, Meinzer FC (2000a) Water utilization, plant hydraulic properties and xylem vulnerability in three contrasting coffee (Coffea arabica) cultivars. Tree Physiol. 20:159-168.

Tausend PC, Meinzer FC, Goldstein G (2000b) Control of transpiration in three coffee cultivars: the role of hydraulic and crown architecture. Trees - Struct. Funct. 14:181-190.

Tesha AJ, Kumar D (1978) Effect of fertilizer nitrogen on drought resistance in Coffea arabica L. J. Agric. Sci. 90: 625-631.

Turner NC (1997) Further progress in crop water relations. Adv. Agron. 58:293-338.

Vaast P, Zasoski RJ, Bledsoe CS (1998) Effects of solution $\mathrm{pH}$, temperature, nitrate/ammonium ratios, and inhibitors on ammonium and nitrate uptake by Arabica coffee in shortterm solution culture. J. Plant Nutr. 21:1551-1564.

Vasudeva N, Venkataramanan D, Raju KI, Ratageri MC (1981) Preliminary studies on the pattern of accumulation of proline in coffee cultivars during drought. Turrialba 31:388390.

Wang W, Vinocur B, Altman A (2003) Plant responses to drought, salinity and extreme temperatures: towards genetic engineering for stress tolerance. Planta 218:1-14.

White DA, Beadle CL, Worledge D (1996) Leaf water relations of Eucalyptus globulus and E. nitens: seasonal, drought and species effects. Tree Physiol. 16:469-476.

Willson KC (1985) Climate and soil. In: Clifford MN, Willson KC (eds), Coffee - Botany, Biochemistry and Production of Beans and Beverage, pp.97-107. Crom Helm, London.

Willson KC (1999) Coffee, Cocoa ant Tea. CAB International, Wallingford.

Wise RP, Naylor AW (1987) Chilling-enhanced photooxidation. The peroxidative destruction of lipids during chilling injury to photosynthesis and ultrastructure. Plant Physiol. 83:272-277.

Wrigley G (1988) Coffee. Tropical Agriculture Series. Longman Scientific \& Technical, Singapore.

Wormer TM (1965) The effect of soil moisture, nitrogen fertilization and some meteorological factors on stomata aperture of Coffea arabica L. Ann. Bot. 29:523-539.

Yeh S, Moffatt BA, Griffith M, Xiong F, Yang DS, Wieseman SB, Sarhan F, Danyluk J, Xue YQ, Hew CL, Doherty-Kirby A, Lajoie G (2000) Chitinase genes responsible to cold encode antifreeze proteins in winter cereals. Plant Physiol. 124:1251-1263.

Xin Z, Browse J (2000) Cold comfort farm: the acclimation of plants to freezing temperatures. Plant Cell Environ. 23: 893-902.

Xu CC, Jeon YA, Lee C-H (1999) Relative contributions of photochemical and non-photochemical routes to excitation energy dissipation in rice and barley illuminated at a chilling temperature. Physiol. Plant. 107:447-453.

Young AJ (1991) The photoprotective role of carotenoids in higher plants. Physiol. Plant. 83:702-708. 